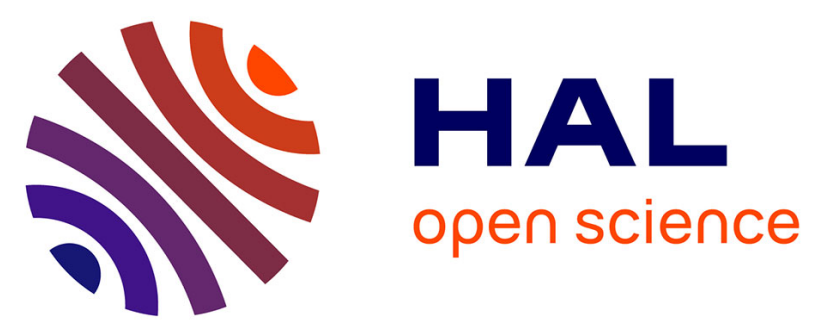

\title{
Low-grade metamorphism around the down-dip limit of seismogenic subduction zones: Example from an ancient accretionary complex in the Shimanto Belt, Japan
}

\author{
Jun Kameda, Hugues Raimbourg, Toshihiro Kogure, Gaku Kimura
}

\section{- To cite this version:}

Jun Kameda, Hugues Raimbourg, Toshihiro Kogure, Gaku Kimura. Low-grade metamorphism around the down-dip limit of seismogenic subduction zones: Example from an ancient accretionary complex in the Shimanto Belt, Japan. Tectonophysics, 2011, 502 (3-4), pp.383-392. 10.1016/j.tecto.2011.02.010 . insu-00576474

\section{HAL Id: insu-00576474 \\ https://hal-insu.archives-ouvertes.fr/insu-00576474}

Submitted on 4 Apr 2011

HAL is a multi-disciplinary open access archive for the deposit and dissemination of scientific research documents, whether they are published or not. The documents may come from teaching and research institutions in France or abroad, or from public or private research centers.
L'archive ouverte pluridisciplinaire HAL, est destinée au dépôt et à la diffusion de documents scientifiques de niveau recherche, publiés ou non, émanant des établissements d'enseignement et de recherche français ou étrangers, des laboratoires publics ou privés. 


\section{Low-grade metamorphism around the down-dip limit of seismogenic subduction zones: Example from an ancient accretionary complex in the Shimanto Belt, Japan}

Jun Kameda ${ }^{1}$, Hugues Raimbourg ${ }^{2}$, Toshihiro Kogure ${ }^{1}$ and Gaku Kimura ${ }^{1}$

${ }^{1}$ Department of Earth and Planetary Science, Graduate School of Science, The University of Tokyo, 7-3-1 Hongo, Bunkyo-ku, Tokyo 113-0033, Japan

${ }^{2}$ Institut des Sciences de la Terre d'Oréans, Université d'Oréans, UMR 6113, Oréans, France

Corresponding author:

Jun Kameda

Department of Earth and Planetary Science, Graduate School of Science, The University of Tokyo

7-3-1 Hongo, Bunkyo-ku, Tokyo 113-0033, Japan

Phone: 81-3-5841-4019

Fax: 81-3-5841-4555

E-mail: kameda@eps.s.u-tokyo.ac.jp 


\begin{abstract}
Reactions involving clay minerals during low-grade metamorphism at the depth of an ancient accretionary complex in the Shimanto Belt, Kyushu, Japan, were studied by integrated transmission electron microscopy-energy dispersive X-ray spectroscopy and X-ray diffraction analyses of the bulk rock and clay fraction. The analyzed metasediment (the Kitagawa unit) contain an incipient sub-horizontal slaty cleavage. Illite crystallinity data and mica $b$ dimensions indicate that the conditions of metamorphic deformation were anchizone-epizone grade and intermediate pressure. Cleavage formation was linked to two reactions involving clay minerals: (1) the recrystallization of $1 M$-dominant matrix mica, inherited from the original sedimentary fabric, into thick, defect-free $2 M_{1}$ packets along cleavage planes; and (2) the formation of chlorite from $7 \AA$ berthierine. Balanced equations among the clay phases, based on compositional data and their relative abundance, suggest that the decomposition of matrix mica resulted in the formation of paragenetic mica and chlorite along the cleavage planes, without significant elemental outflux. Although a modal increase in phyllosilicates is not indicated by the data, the growth of chlorite and mica along cleavage planes may have a large influence on the rheological properties of a décollement and may be related to the occurrence of the seismic-aseismic transition at $\sim 350{ }^{\circ} \mathrm{C}$.
\end{abstract}

Key words: accretionary prism; low-grade metamorphism; mica; chlorite; X-ray diffraction; transmission electron microscopy 


\section{Introduction}

The mechanical properties of sediments entering a subduction zone are progressively modified by dewatering, lithification, and deformation (Cowan, 1982; Byrne, 1984; Taira et al., 1992; Moore et al., 2001; Moore and Saffer, 2001; Hashimoto et al., 2006; Kimura et al., 2007). Such modification along a plate boundary fault (i.e., a décollement) has a major influence on several aspects of accretionary prism dynamics, such as wedge geometry, internal structure, and seismicity (Wang and Hu, 2006; Hyndman, 2007; Kimura et al., 2007). In general, a décollement can be divided into three segments in terms of its mechanical regime: shallow and deep aseismic portions, and an intermediate seismic region (Hyndman et al., 1997; Hyndman, 2007). The upper of the two seismic-aseismic transitions occurs at temperatures of $\sim 150{ }^{\circ} \mathrm{C}$ and is believed to be related to dewatering of subducted sediments due to tectonic loading and diagenetic dehydration reactions (e.g., smectite-illite transition and opal-quartz transition), which allow increase in effective normal stress of the décollement (Moore and Saffer, 2001; Spinelli and Saffer, 2004). Moreover, active carbonate, clay and quartz cementations around this temperature condition may cause sliding instability of the sediments (Moore and Saffer, 2001). On the other hand, onset of the aseismic behavior above $\sim 350{ }^{\circ} \mathrm{C}$ is inferred to be related to the mechanical properties of subducted sediments subjected to low-grade metamorphism (Hyndman et al., 1997; Hyndman, 2007).

Although the nature of deep crustal structure in subduction zones remains debated, several seismic reflection surveys (particularly those undertaken at the Cascadia margin) suggest that the décollement widens with increasing depth to be several kilometers thick, forming reflection banding in a seismic profile (e.g., Nedimovic et al., 2003; Calvert et al., 2006). A candidate 
material for such reflectors is plastically deformed metasediments affected by low-grade metamorphism, with a structure similar to that of mylonite zones. Therefore, phase transitions in subducted sediments, particularly those for phyllosilicates, are likely to influence aseismic faulting along deep décollements (Hyndman et al., 1997; Hyndman, 2007). Nevertheless, the brittle-ductile transition is rarely exposed at the surface, as most accretionary prism rocks do not reach the transition or are overprinted by late-stage higher-grade metamorphism. Consequently, little is known of the prograde evolution of mineral assemblages and their reaction pathways around the down-dip part of the seismogenic zone, which may control the mechanical transition from seismic to aseismic behavior.

The Kitagawa unit, exposed on the easternmost side of the Kyushu Shimanto Belt, Japan, provides an opportunity to trace the progress of low-grade metamorphism within a subduction zone, because this unit records the highest metamorphic grade of the rocks within the Shimanto Belt (320-330 ${ }^{\circ} \mathrm{C}$; Kondo et al., 2005) and comprises a complete succession ranging from shale/sandstone to intensely cleaved metasediment (Raimbourg et al., 2009). A structural analysis of the unit indicates that vertical loading, probably in a setting around the plate interface, produced the ubiquitous subhorizontal cleavage defined by networks of recrystallized chlorite and mica (Raimbourg et al., 2009).

Illite crystallinity (IC) measurements on micas of the Kitagawa unit (Mukoyoshi et al., 2007, 2009) yield lower values at a site located close to the Nobeoka Thrust $\left(0.24 \Delta^{\circ}\right)$ compared with a site located more than $5 \mathrm{~km}$ from the thrust $\left(0.31 \Delta^{\circ}\right)$. Because the intensity of deformation in this unit shows an increase toward the Nobeoka Thrust (Raimbourg et al., 2009), the observed trend in IC values is inferred to reflect the extent of mica growth, although additional analyses 
are needed to characterize the complete sequence of metamorphic processes that occurs during the formation of a mature metapelite.

The aim of the present study is to clarify several aspects of low-grade metamorphism of the Kitagawa unit, including its metamorphic setting, evolution of the mineral assemblage and bulk chemistry, and the reaction pathways of clay minerals. To this end, we subjected bulk samples and the clay fraction $(<2 \mu \mathrm{m})$ to quantitative analyses by X-ray diffraction (XRD) and high-resolution transmission electron microscopy (HR-TEM), for samples that record varying degrees of deformation. Based on these data, we discuss the influence of low-grade metamorphism on the aseismic behavior of deep décollements.

\section{Geological setting}

The Shimanto Belt is an ancient accretionary complex that extends for $800 \mathrm{~km}$ along the Pacific side of southwest Japan (Fig. 1a). The belt is divided into northern and southern sub-belts, separated by the Aki Tectonic Line in the Shikoku and Kii regions, and by the Nobeoka Thrust in Kyushu. In eastern Kyushu, the Kitagawa Group was exhumed north of the Nobeoka Thrust, emplaced over the southern Hyuga Group (Fig. 1b). Metamorphic mineral assemblages suggest that the northern belt was metamorphosed in the greenschist facies (Toriumi and Teruya, 1988), whereas the southern belt was metamorphosed in the prehnite-pumpellyite to zeolite facies.

The Kitagawa unit, a turbiditic sequence of alternating sandstone- and mudstone-rich layers that contain Eocene radiolarian fossils (Ogawaguchi et al., 1984), records two stages of deformation: an early stage of horizontal contraction, characterized by folding and thrusting, was overprinted by the development of a pervasive slaty cleavage during vertical shortening 
(Raimbourg et al., 2009). The slaty cleavage is more pronounced in the deeper levels of the Kitagawa unit; i.e., closer to the Nobeoka Thrust.

Vitrinite reflectance values (\% Rm) obtained for the Kitagawa unit range from 5.33 to 5.63 (Kondo et al., 2005), corresponding to maximum paleotemperatures of $320-330{ }^{\circ} \mathrm{C}$ based on the method proposed by Sweeney and Burnham (1990). These temperatures are similar to the estimated formation temperature of metamorphic chlorite (Raimbourg et al., 2009).

The Hyuga Group, located south of the Nobeoka Thrust, possesses a shale-dominant mélange texture. Vitrinite reflectance data indicate temperatures of $250-270{ }^{\circ} \mathrm{C}(\% \mathrm{Rm}=2.58-2.75$; Kondo et al., 2005), which are 50-80 ${ }^{\circ} \mathrm{C}$ lower than those obtained for the Kitagawa unit. This difference in temperature suggests that the Nobeoka Thrust was active as an out-of sequence thrust (Ohmori et al., 1997), responsible for exhuming the unit from deep within the accretionary complex (Raimbourg et al., 2009). Faulting is thought to have occurred during 40-48 Ma, as inferred from illite $\mathrm{K}-\mathrm{Ar}$ and zircon fission track ages (Hara and Kimura, 2008).

\section{Experimental procedure}

Samples with various densities of cleavage planes were collected from the Kitagawa unit and were classified into the three groups proposed by Raimbourg et al. (2009): non-cleaved samples (NM) do not contain slaty cleavage; slightly cleaved samples (SIM) possess both cleavage and bedding; and strongly cleaved samples (StM) contain an intensively developed cleavage with little sign of the original bedding fabric. A total of 13 samples (6 NM samples, 3 SIM samples, and 4 StM samples) were analyzed (Table 1). 
Representative portions of each sample were ground using a vibrational mill for 2 minutes under dry conditions for bulk XRD analyses. Each powder, mixed with high-purity corundum (AX-5H, Hinomoto Kenmazai Co., Japan) as an internal standard, was mounted on an XRD glass holder in a side-load manner to minimize any preferred alignment of phyllosilicates. The patterns were recorded using a Rigaku Rint-2000 with monochromatized $\mathrm{Cu} K \alpha$ radiation at 40 $\mathrm{kV}$ and $30 \mathrm{~mA}$, with $1^{\circ}$ divergence and anti-scattering slits, and a $0.3 \mathrm{~mm}$ receiving slit. The $2 \theta$ range of $2^{\circ}-65^{\circ}$ was scanned in step scan mode for $4 \mathrm{~s}$, at steps of $0.04^{\circ} 2 \theta$. The RockJock program, developed by Prof. D.D. Eberl (Eberl, 2003), was used for quantitative analyses of rock composition. The XRD patterns were fitted using reference patterns for quartz, albite, calcite, pyrite, $1 M$ and $2 M_{1}$ micas, and trioctahedral chlorite, as stored in the program.

To obtain the clay size fraction $(<2 \mu \mathrm{m})$, rock chips were gently crushed by hand and dispersed ultrasonically in distilled water. The clay fraction was then separated by centrifugation and used for oriented analyses of clay minerals in air-dried (AD) and ethylene-glycolated (EG) states. The Newmod program (Reynolds, 1985) was used to interpret the XRD patterns. IC was measured based on the width of the $10 \AA$ peak at half height, under the AD condition (Kübler, 1968). The $b$ dimension of mica was determined using the d-value of the mica 060 peak calibrated by the 221 peak of quartz at $1.541 \AA$ (Merriman and Peacor, 1999).

The TEM was operated at $200 \mathrm{kV}$ to observe fine structures in minerals (JEM-2010, JEOL, Japan). Some TEM images were digitized using a CCD camera and processed to remove noisy contrast due to amorphous materials on the specimen surface, using a Wiener-filter (Marks, 1996; Kilaas, 1998) developed by K. Ishizuka (HREM Research, Inc.), as implemented in Gatan Digital Micrograph version 3.10.0. The clay fraction powders were dispersed on a holey carbon 
film supported by a $\mathrm{Cu}$-grid for chemical analysis by energy dispersive X-ray spectrometer (EDX) in the TEM (EX-24025JGT, Jeol). To minimize the loss of alkali elements, which is significant in the analysis of clay minerals (van der Pluijm et al., 1988), beam diameter was extended to $200 \mathrm{~nm}$ and the counting duration was reduced to 30 seconds. Each grain was planarly exposed such that its $c^{*}$ axis was rotated by $20^{\circ}$ from the beam axis toward the EDX detector. Quantitative chemical analyses were performed with $k$-factors for $\mathrm{O}, \mathrm{Na}, \mathrm{Mg}, \mathrm{Al}, \mathrm{Si}, \mathrm{K}$, $\mathrm{Ca}, \mathrm{Ti}, \mathrm{Mn}$, and Fe determined from standard samples of biotite, albite, olivine, and hornblende. The atomic ratio was obtained by correcting for the effect of X-ray absorption by the specimen under the criterion of charge neutrality (Van Cappellen and Doukhan, 1994), using a program developed by one of the authors (T. Kogure).

\section{Results}

\subsection{Deformation structures within sediment of the Kitagawa unit}

Microstructures and deformation stages of the Kitagawa unit have been described in detail by Raimbourg et al. (2009), and are briefly summarized here. The protolith of the low-grade metamorphic rocks is a turbiditic unit that was buried deep within the Shimanto paleo-accretionary prism, down to the base of the inner wedge. The protolith consists of alternating sandstone- and mudstone-rich layers with thicknesses of $2 \mathrm{~mm}$ to $10 \mathrm{~cm}$. The sediment consists mainly of detrital quartz and minor plagioclase clasts embedded in a fine-grained matrix. The sandstone-rich layers contain a larger proportion of clasts than do the mudstone-rich layers. A small amount of detrital mica grains is scattered throughout the rock, with the grains being larger in the sandstone-rich layers (Fig. 2a, b, and b'). The microcrystalline 
matrix is too fine-grained for its mineralogical composition to be determined optically.

Macroscopically, the deformation is characterized by the development of a subhorizontal slaty cleavage that crosscuts and disrupts the original sedimentary fabrics. Structural and magnetic (AMS) analyses indicate that the kinematics of the associated deformation is mainly coaxial shortening, with a compressive axis oriented close to vertical (Raimbourg et al., 2009). At the microscopic scale, the cleavage consists of a dense network of mica and chlorite surrounding quartz and feldspar grains (Fig. 2c and c'). Both of these phyllosilicates have a shape-preferred orientation that defines the foliation, as indicated by their simultaneous extinction when rotating the microscope stage under cross-polarized light (Fig. 2c'). Micas are large (up to $100 \mu \mathrm{m}$ long), while chlorite grains consist mostly of very thin, entangled fibers.

\subsection{XRD analyses of the clay fraction}

The Kitagawa unit contains a simple and uniform mineral assemblage through the succession, comprising quartz, plagioclase (albite), and phyllosilicates with accessory pyrite, Fe oxides, and rare calcite. However, as shown below, the abundance, composition, and crystallographic features of the phyllosilicates are progressively modified at different stages of cleavage formation. Figure 3 shows typical XRD patterns of the $<2 \mu \mathrm{m}$ size fraction for NM, SIM, and StM samples. The most common phase is dioctahedral mica. Table 1 summarizes the IC values of the analyzed samples. IC values for NM samples show a wide scatter from 0.20 to $0.41 \Delta^{\circ}$, while those for SIM samples are $0.22-0.29 \Delta^{\circ}$, and those for StM samples are within a limited range around $0.2 \Delta^{\circ}$. The lowest of the IC values obtained for NM samples $\left(\sim 0.2 \Delta^{\circ}\right)$ probably reflect the presence of detrital mica, whereas a sharpening of the 001 reflection through SIM and 
StM indicates the thickening of mica grains, which is ascribed mainly to recrystallized mica along cleavage planes. These IC values indicate that the low-grade metamorphism of this unit corresponds to the anchizone-epizone grade (the values that define the boundary between the diagenetic zone and the anchizone, and between the anchizone and epizone, are 0.42 and $0.25 \Delta^{\circ}$, respectively; Merriman and Peacor, 1999). Although the present IC values are not interlaboratory standardized, comparable values have been reported from samples obtained near the Nobeoka Thrust (0.24 $\Delta^{\circ}$; Mukoyoshi et al., 2009) and from the northern part of the unit $\left(0.31 \Delta^{\circ}\right.$; Mukoyoshi et al., 2007), for which the IC indexes were measured using the JIC (Japanese Illite Crystallinity Standard) scale, which was developed for paleothermal analyses of accretionary complexes (Hara and Kimura, 2003). JIC values are converted to the widely accepted CIS (Crystallinity Index Standard; Warr and Rice, 1994) by the following relation (Hara and Kimura, 2003): IC $($ CIS $)=1.55 \times$ IC $($ JIC $)-0.07$. For instance, the value of $0.24 \Delta^{\circ}(\mathrm{JIC})$ obtained at the southernmost part of the unit, within intensely cleaved rock (Mukoyoshi et al., 2009), is converted to $0.3 \Delta^{\circ}$ (CIS), corresponding to the metamorphic conditions of the boundary between the low and high anchizone (Merriman and Peacor, 1999). Metapelites of this grade commonly contain an incipient cleavage (Merriman and Peacor, 1999), which is consistent with the rocks of the present study area.

The $b$ length of mica has been used as a semi-quantitative barometer of crystallization conditions (Sassi and Scolari, 1974; Guidotti and Sassi, 1986). An increase (decrease) in $b$ length is caused mainly by a greater (smaller) extent of phengite substitution (Guidotti et al., 1989). In the present study, the $b$ values determined from mica 060 reflections range from 9.008 to 9.033 $\AA$ (Table 1). The relatively deformed samples yield lower $b$ values (Table 1), suggesting a 
reduction of phengitic content in recrystallized mica toward more aluminous muscovite.

The relative abundance of different polytypes in micas was qualitatively determined by analyzing random mounts of the clay fraction using XRD (Fig. 4). According to Caillère et al. (1982) and Dalla Torre et al. (1994), $I(112)$ of $1 M$ and $I(025)$ of $2 M_{1}$ are good indices for estimating the relative abundance of these polytypes because of their low sensitivity to the effect of mica preferred orientation or overlap with the feldspar peak. The intensity relations between the two reflections indicate a progressive transition from $1 M$ to $2 M_{1}$ from NM through SIM and StM (Fig. 4).

In addition to mica, chlorite occurs as a clay phase. Although chlorite does not appear in some of the NM samples, the $14 \AA$ and $7 \AA$ peaks become more distinctive with increasing metamorphic grade (Fig. 3). This observation indicates the progressive growth of chlorite within the slaty cleavage. However, the intensity of the $7 \AA$ reflection relative to that of $14 \AA$ is much higher than that of a theoretical chlorite XRD pattern, using a structural formula determined by the present EDX analyses (see Section 4.5.). This discrepancy is probably caused either by peak overlap with another $7 \AA$ phase or the interstratification of $7 \AA$ layers within the chlorite stacking; the latter is more probable, given the broad and diffuse 001 reflection (Reynolds, 1988). Such a broad 001 peak is more common in NM than in SIM and StM samples (Table 1).

A candidate material for the $7 \AA$ phase in metapelites is kaolin minerals. We tested for the occurrence of kaolin by performing an acid treatment test $(2$ hours immersed in $1 \mathrm{~N} \mathrm{HCl}$ at $\left.60{ }^{\circ} \mathrm{C}\right)$. The complete disappearance of the $7 \AA$ peak after the test suggests that the mineral is more likely to be Fe-bearing berthierine, which is highly reactive with acid. The occurrence of chlorite-berthierine, as well as the fine structures of micas, was further examined by TEM (see 
Section 4.4.).

\subsection{Quantitative bulk-rock composition determined by RockJock}

The nature of prograde changes in the bulk-rock composition was quantitatively analyzed using RockJock (Eberl, 2003), which can be used to estimate the relative proportions of different polytypes in illite-muscovite (Aldega and Eberl, 2005). Accessory minerals (e.g., Fe oxides and rutile) occur in trace amounts $(<0.5 \mathrm{wt} \%)$ and were excluded from the analyses. Table 1 lists the obtained relative abundances (wt\%). Using this program, the total weight percent is a measure of analytical quality, because the content of each mineral is estimated independently with respect to the internal standard of corundum (Eberl, 2003). In the present study, the deviation from a total of $100 \%$ is within $\pm 2 \%$, except for one sample (Table 1), indicating the high quality of the analyses. The data for the sample that yielded a low total (HN24) were recalculated to $100 \%$, to enable a comparison with the other samples.

Figure 5a shows a clear trend of $1 M$-to- $2 M_{1}$ conversion in micas with progressive deformation; NM samples show a wide range of $1 M /\left(1 M+2 M_{1}\right)$ values, ranging from 0.3 to 1.4 , but values are below 0.1 in StM samples. This finding is consistent with XRD analyses of the clay fraction (Fig. 3). This reaction is concomitant with the growth of chlorite (Fig. 5b). Although chlorite is scarcely distributed and is sometimes absent in NM, it makes up approximately $40 \%$ of the mica content in StM samples. Such chlorite growth is also qualitatively compatible with the results of XRD analyses of the $<2 \mu \mathrm{m}$ fraction (Fig. 3).

Variations in the total clay content, which have a strong influence on rheology (e.g., Brown et al., 2003), are shown as the summation of $1 M$ mica, $2 M_{1}$ mica, and chlorite (Fig. 5c). The clay 
content does not show a large increase with cleavage formation (showing an average change of 1 wt\% from NM to StM; Table 1), but the large variation in NM samples is reduced to a uniform composition with cleavage development. The initial variation in NM samples probably reflects variations in grain size (i.e., the ratio of clay- to silt-size grains) within the bulk samples, which are subsequently homogenized in terms of rock composition and fabric by the recrystallization and neocrystallization of phyllosilicates along cleavage planes, thereby diminishing the original sedimentary-related variations.

\subsection{Microtextural and crystallographic analyses of phyllosilicates by TEM}

The analyzed metapelite contains basically two forms of micas (Raimbourg et al., 2009): matrix mica inherited from the original sedimentary fabric, and recrystallized mica that defines the cleavage. TEM images showed that the matrix mica has variable packet thickness, from $<30$ $\mathrm{nm}$ to $>100 \mathrm{~nm}$, with several strain features such as voids and layer terminations (white arrows in Fig. 6a). In places, we observed relatively ordered, selected-area electron diffraction (SAED) patterns with dominantly $1 M$ stacking, although accompanied by packets showing two-layer $\left(2 M_{1}\right)$ periodicities (Fig. 6b). Stacking disorders are visible, even in crystals that yield ordered ED patterns (Fig. 6b).

Recrystallized mica that occurs along cleavage planes has a relatively homogeneous thickness (mostly $>100 \mathrm{~nm}$ ) and has fewer defects than the matrix mica (Fig. 6c). Although $1 M$ was occasionally present, $2 M_{1}$ was more commonly observed.

Chlorite occurs as well-defined packets (>100 nm thick) and is oriented parallel to the cleavage (Fig. 7a). Lattice fringe images reveal the presence of $7 \AA$ berthierine (Fig. 7b and c), 
which is generally intergrown with $14 \AA$ chlorite layers at the monolayer level rather than forming discrete packets. In some cases, berthierine constitutes the larger fraction of a single packet (Fig. 7b). The interstratification of berthierine and chlorite is commonly observed in diagenetic to low-grade metamorphic rocks (Lee et al., 1984; Ahn and Peacor, 1985; López-Munguira and Nieto, 2000) and in synthetic samples (Velde, 1973; James et al., 1976). The interstratified phases are considered to represent a transient state toward a mature chlorite. In Fig. 7d, two berthierine layers (TOTO) are transformed to a single chlorite layer (TOT and one brucite-like B layer) by tetrahedral inversion (white bracket in the figure), strongly suggesting a solid-state conversion, as discussed in detail by Xu and Veblen (1996).

\subsection{TEM-EDX chemical analyses}

The chemical compositions of chlorite in the present samples were measured by Raimbourg et al. (2009) using electron microprobe analyzer (EMPA), and were employed to estimate the formation temperature of chlorite based on the chemical thermometer developed by Vidal and Parra (2000). However, the grain size of clays is generally too small to be measured satisfactorily by EMPA; thus, we re-examined the composition of mica and chlorite by EDX in TEM (Tables 2 and 3). The Si content of micas in NM samples ranges from 3.0 to 3.5 if normalized to $\mathrm{O}_{10}(\mathrm{OH})_{2}$, but the range of values is smaller in SIM and StM samples (3.1-3.3), which have a high interlayer charge; i.e., $\mathrm{Na}+\mathrm{K}=\sim 1.0$ (Fig. 8a). The interlayer composition is characterized by a low $\mathrm{Na}$ content $(\mathrm{Na} /(\mathrm{Na}+\mathrm{K})<0.15)$ for all deformation stages (Table 2). In addition to a low interlayer deficiency, SIM and StM samples have low Mg + Fe contents (Fig. 8b) and a small $\mathrm{Fe} /(\mathrm{Fe}+\mathrm{Mg}$ ) ratio (Fig. 8c) compared with NM. The depletion in mafic elements is consistent 
with the low phengitic content inferred from the lower $b$ dimensions in SIM and StM samples (Table 1).

Figure 9 shows the chemical compositions of chlorite determined by TEM-EDX, along with data measured by EMPA (Raimbourg et al., 2009). The two techniques yield comparable results, indicating that element contamination during EMPA is not significant. There is almost no compositional variation among the samples of different metamorphic grade.

\section{Discussion}

\subsection{Clay mineral reactions in the Kitagawa unit during anchizone-epizone grade}

\section{metamorphism}

The exposure of a series of lithologies ranging from shale/sandstone with well-preserved sedimentary fabrics to moderately or intensely deformed slates enables a discussion on the change in mineralogy that occurs during cleavage formation in the Kitagawa unit. As shown above, clay minerals in the unit are restricted to two types: dioctahedral micas and trioctahedral chlorite. Although many factors (e.g., temperature, pressure, bulk rock composition, and fluid-rock ratio) may affect the mineral assemblage and its evolution in low-grade metamorphic rocks (Merriman and Peacor, 1999), Merriman (2002) showed that the clay mineralogy of a slate belt in the British Isles is strongly dependent on the regional geotectonic setting. Many different species of clay minerals can be observed in extensional basins, including the aluminous kaolin-pyropyllite and sodium mica-paragonite series, as well as dioctahedral K-mica and the trioctahedral 2:1 series. This variation in clay mineralogy is due to intense seawater circulation or the intrusion of volcanic rocks, especially during sedimentation (Merriman, 2002). In contrast, 
the restricted circulation of seawater or absence of high- $\mathrm{Na} / \mathrm{K}$ fluids may reduce such diversity in convergent basins (Merriman, 2002). This may explain the poor diversity of clay minerals in the present samples, as well as the absence of kaolin and pyrophyllite, and the low sodium content in the mica interlayer.

Despite the invariant K-dominant interlayer composition, the crystallographic features of mica are modified by deformation-induced recrystallization. Bulk-rock XRD analyses and microscopic observations by TEM suggest that the matrix mica, which is $1 M$, is converted to $2 M_{1}$ packets along cleavage planes. In addition, strain-related structures are healed to form thick, defect-free packets, which is also indicated by the low IC values obtained for deformed samples. Such crystallographic maturation has been widely recognized in anchizone-grade metapelites that show the development of incipient slaty cleavage (Lee et al., 1986; Li et al., 1994).

Unlike the characteristic conversion of micas, the origin of chlorite is somewhat problematic. Chlorite in metapelites is commonly derived from a prograde reaction that originates from trioctahedral smectite via corrensite (e.g., Hillier, 1993; Schmidt and Livi, 1999). However, the formation of $\mathrm{Fe}-\mathrm{Mg}$-rich smectite within an accretionary prism is generally localized to specific lithologies such as incorporated oceanic crust (e.g., Kameda et al., in review), which is not found in the Kitagawa unit. Previous studies have noted that chlorite forms via the conversion of dioctahedral smectite to illite (Hower et al., 1976; Ahn and Peacor, 1985), because of the typical depletion of mafic elements in illite relative to the starting smectite (Drief and Nieto, 2000). In the present case, however, the chlorite content is generally low prior to deformation (Fig. 5b) and it is locally absent, despite the completion of smectite-to-illite conversion, which typically occurs at $<150{ }^{\circ} \mathrm{C}$. This reaction may have contributed to some of the chlorite in the NM samples, but 
the progressive growth of chlorite from the SIM to StM samples (Fig. 11b) requires another process, possibly the decomposition of matrix mica of phengitic composition to form paragenetic mica and chlorite along cleavage planes. The likelihood of this reaction is evaluated with reference to the following balanced equation. We roughly consider that the increment of chlorite from NM to StM samples (by $10 \mathrm{wt} \%$ on average) and the total mica content in StM samples (22 $\mathrm{wt} \%$ ) reflect the effects of recrystallization. Based on the chemical composition determined by EDX (Tables 2 and 3), the molar weight of mica and chlorite per structural formula in StM samples is 395 and 636, respectively. Then, the molar ratio of the final product between the total mica content in StM samples $(22 \mathrm{wt} \%)$ versus the increase in chlorite content from NM to StM samples $(10 \mathrm{wt} \%)$ is estimated to be $22 / 395: 10 / 636=1: 0.275$. Assuming the amount of $\mathrm{Al}_{2} \mathrm{O}_{3}$ to be constant throughout the reaction, the molar ratio of the starting material (mica in NM samples) required to complete the reaction is derived from the flowing equation:

$$
\begin{aligned}
& 1.35 \times\left(\mathrm{K}_{0.83} \mathrm{Na}_{0.06}\right)\left(\mathrm{Fe}_{0.17} \mathrm{Mg}_{0.28} \mathrm{Al}_{1.64}\right)\left(\mathrm{Si}_{3.22} \mathrm{Al}_{0.70} \mathrm{Ti}_{0.08}\right) \mathrm{O}_{10}(\mathrm{OH})_{2} \rightarrow \\
& \left(\mathrm{K}_{0.92} \mathrm{Na}_{0.05}\right)\left(\mathrm{Fe}_{0.1} \mathrm{Mg}_{0.26} \mathrm{Al}_{1.68}\right)\left(\mathrm{Si}_{3.24} \mathrm{Al}_{0.72} \mathrm{Ti}_{0.04}\right) \mathrm{O}_{10}(\mathrm{OH})_{2}+ \\
& 0.275 \times\left(\mathrm{Al}_{1.54} \mathrm{Fe}_{2.7} \mathrm{Mg}_{1.6}\right)\left(\mathrm{Si}_{2.70} \mathrm{Al}_{1.22} \mathrm{Ti}_{0.07}\right) \mathrm{O}_{10}(\mathrm{OH})_{8}+0.16 \mathrm{~K}^{+}+0.023 \mathrm{Na}^{+}-0.45 \mathrm{Fe}^{2+}- \\
& 0.24 \mathrm{Mg}^{2+}+0.03 \mathrm{Ti}^{4+}+0.27 \mathrm{Si}^{4+} \quad \text { (1). }
\end{aligned}
$$

This equation indicates that about $30 \mathrm{wt} \%(=22 \mathrm{wt} \% \times 1.35)$ of the starting material is needed, which is compatible with the average mica content in NM samples (31 wt $\%)$. The mass balance results, based on $\mathrm{Al}$ conservation, support the validity of reaction (1). However, this reaction requires the presence of $\mathrm{Mg}^{2+}+\mathrm{Fe}^{2+}$. The origin of these elements is uncertain, but may have been other mafic minerals such as detrital biotite, pyrite, or Fe-oxides.

When this reaction proceeds, berthierine may occur as a precursor. As mentioned above, the 
XRD patterns of the oriented clay preparations show a weak, broad $14 \AA$ reflection relative to pure chlorite (001), which is ascribed to interstratification between berthierine and chlorite. Hillier and Velde (1992) used NEWMOD (Reynolds, 1985) to calculate the one-dimensional XRD pattern of interstratified chlorite-berthierine with a variable mixture ratio, and obtained a near-linear correlation between berthierine content $(5 \%-35 \%)$ and width $\left({ }^{\circ} 2 \theta\right)$ at half the height

of the $14 \AA$ peak, independent of chemistry and crystallite thickness. Our experimental patterns show a sharpening of the $14 \AA$ peak from NM samples $(0.25-0.37$ of width at half peak height; average, 0.282$)$ to SIM (0.265) and StM (0.192) (Table 1). Based on fig. 7 in Hillier and Velde (1992), NM is estimated to contain $>5 \%$ berthierine. The reduction in berthierine content is interpreted to reflect post-precipitated conversion from berthierine layers to mature chlorite in a solid-state manner, as observed by TEM (Fig. 7d).

\subsection{Element flux during cleavage formation}

The mass flux of elements during slate formation has been extensively studied in recent decades. For example, studies of kinematic strain (e.g., Write and Platt, 1982; Beutner and Charles, 1985; Brandon et al., 1991) have shown a significant volume loss (30\%-60\%) in slates, but Erslev (1998) noted that such estimates are based on a misinterpretation of complicated, heterogeneous strain and metamorphic reactions, and emphasized the near-isochemical nature of the slates, as also indicated by geochemical signatures (Shaw, 1954; Ague, 1991; Wintsch et al., 1991). The extent of element flux may be recorded in the resultant mineral assemblage, but few studies have provided quantitative data on slate composition. Ward and Gomez-Fernandez (2003) applied the Rietveld method to Spanish roofing slates, and assessed the applicability of 
quantitative analyses with respect to the bulk chemical composition, although the authors did not quantify the degree of modal change during slate formation.

Lee et al. (1986) performed a semi-quantitative XRD analysis of mudstone/slate samples and compared the relative intensity of the constituent minerals, indicating an approximately homogeneous rock composition across the lithologic trnsition. The quantitative data of the present study indicate a near-constant modal composition, considering the average values for samples from each deformation stage (Table 1). For example, the content of quartz, which is one of the main mobile elements, deviates by just $\sim 4 \mathrm{wt} \%$ from $40 \mathrm{wt} \%$; thus, it is unlikely that volume outflux occurred on the order of several tens of weight percent.

Van de Kamp (2008) suggested that measurable amounts of $\mathrm{SiO}_{2}(\sim 20 \mathrm{wt} \%)$ are released by the illite-to-muscovite conversion. Equation (1) indicates that the production of 1.0 mole of cleavage-parallel mica leads to 0.26 moles of $\mathrm{SiO}_{2}$ release, corresponding to $1 \mathrm{wt} \%$ at most (= 22 $w t \% \times 0.26 \times 60 / 395)$. Thus, in the present case, negligible amounts of $\mathrm{SiO}_{2}$ were released via reactions involving clay minerals.

Raimbourg et al. (2009) performed XRF analyses of bulk samples (the same samples as those analyzed in the present study), revealing that the concentration of immobile $\mathrm{TiO}_{2}$ is inversely related to the concentration of mobile $\mathrm{SiO}_{2}$. The authors proposed that any outflow of $\mathrm{SiO}_{2}$ would have been caused primarily by quartz dissolution. However, in terms of the relation between $\mathrm{SiO}_{2}$ content and deformation, their data show a high degree of scatter. This result, combined with the constant modal composition of samples of variable metamorphic grade, suggests that $\mathrm{SiO}_{2}$ outflow occurred prior to cleavage formation, during diagenesis at shallow levels (e.g., Renard et al., 1999; Yang, 2000; Kawabata et al., 2007); thus, high fluxes of 
elements would not have occurred during anchizone metamorphism.

\subsection{Geotectonic setting of the Kitagawa unit and implications for the weak and aseismic nature of the deep décollement}

Previous studies have estimated the peak paleotemperature of the Kitagawa unit. Based on vitrinite reflectance values, Kondo et al. (2005) estimated thermal maturation at $320-330{ }^{\circ} \mathrm{C}$. Application of the chlorite geothermometer developed by Vidal and Parra (2000) yielded an average temperature of $\sim 272{ }^{\circ} \mathrm{C}$ (Raimbourg et al., 2009), although the data show a wide scatter corresponding to temperatures of $200-400{ }^{\circ} \mathrm{C}$. Mukoyoshi et al. (2007) and Underwood et al. (1993) derived regression equations for IC-temperature relations applicable to paleothermal analysis of the Shimanto accretionary complex. The IC value of $0.24 \Delta^{\circ}$ obtained near the Nobeoka Thrust (Mukoyoshi et al., 2009) corresponds to temperatures of $304 \pm 30{ }^{\circ} \mathrm{C}$ and $330{ }^{\circ} \mathrm{C}$, respectively. The use of our IC value for StM samples $\left(0.2 \Delta^{\circ}\right)$ yields slightly higher temperatures of $312 \pm 30{ }^{\circ} \mathrm{C}$ and $347{ }^{\circ} \mathrm{C}$. Considering these estimates, a metamorphic temperature of $300-350{ }^{\circ} \mathrm{C}$ is an appropriate estimate for the Kitagawa unit.

Although there are few direct constraints on the peak burial depth, Raimbourg et al. (2009) estimated a minimum burial depth of $\sim 6 \mathrm{~km}$ based on a high geothermal gradient of $50{ }^{\circ} \mathrm{C} / \mathrm{km}$ in the Eocene, influenced by the subduction of a young, hot oceanic plate (Sakaguchi, 1999). This high regional geotherm may be overestimated.

The $b$ dimensions of micas in the analyzed samples show a narrow range of 9.01-9.03 (9.02 $\AA$ on average; Table 1), and StM samples yield values on the lower side of this range ( $9.01 \AA)$. According to the regression relation between cell parameters and the composition of 
$2 M_{1}$ mica (Guidotti et al., 1989), a $b$ dimension of $\sim 9.01 \AA$ is estimated to correspond to a $\mathrm{Mg}+$ Fe content of 0.4 in the case of an interlayer composition of $\mathrm{Na} /(\mathrm{Na}+\mathrm{K})<0.15$, which is consistent with the mica composition determined independently by EDX (Table 2). The consistency of the two parameters indicates that the $b$ dimension is a reliable measure of metamorphic conditions, as suggested by Abad et al. (2003). The $b$ dimensions obtained in the present study, which range from 9.01 to 9.03 (Table 1), are within the values of 9.0 and 9.04 assigned by Guidotti and Sassi (1986) to the lower/upper limit of the intermediate-pressure facies series for a geothermal gradient of $25-35{ }^{\circ} \mathrm{C} / \mathrm{km}$. Although the thermal structure of a subduction zone may show some longitudinal variations rather than being isothermal (e.g., Nankai, Watanabe et al., 1970; Yamano et al., 1984, 2003), the Kitagawa unit may have experienced burial in an area with a geothermal gradient of $25-35^{\circ} \mathrm{C} / \mathrm{km}$, at least at the time of mica formation. At this time, the minimum burial depth of the Kitagawa unit would have been at least $8.5 \mathrm{~km}$, further supporting the proposal by Raimbourg et al. (2009) that the rock has been transported far below the frontal contractional setting of the prism $(4-5 \mathrm{~km}$ thick in the case of modern complexes), where it was subjected to vertical compaction (Raimbourg et al., 2009).

It is uncertain how closely the Kitagawa unit approached the ancient décollement, but temperatures of $300{ }^{\circ} \mathrm{C}$ or more suggest a vertical separation of less than $2 \mathrm{~km}$ (for a geothermal gradient of $25-30{ }^{\circ} \mathrm{C} / \mathrm{km}$ ), if the unit was located just above the area where the $350{ }^{\circ} \mathrm{C}$ isotherm intersects the décollement. This distance (between the Kitagawa unit and the décollement) increases (decreases) as the location of the unit is shifted landward (seaward).

Seismic reflection surveys of the Cascadia margin (Nedimovic et al., 2003; Calvert et al., 
2006) suggest that a deep aseismic décollement has a banded reflection structure, extending regionally at depths of 5-8 $\mathrm{km}$ from the top of the subducting slab. These studies proposed that the structure corresponding to this reflector is a ductile shear zone composed of foliated metasediment. It is likely that subhorizontal slaty cleavage within the Kitagawa unit would produce such a seismic structure.

Previous sliding experiments on crustal rock (granite) indicate that the seismic-aseismic transition occurs at $\sim 350{ }^{\circ} \mathrm{C}$, possibly related to pressure solution creep of quartz (Blanpied et al., 1991, 1995). This observation may explain the down-dip limit of seismogenic subduction zones (Hyndman et al., 1997). However, the sediments analyzed in the present study are rich in phyllosilicates, meaning that it is uncertain whether the rheology of the subducted sediments is controlled by quartz deformation. In the case of the Kitagawa unit, we consider that chlorite growth would have had a marked effect on the bulk-rock rheology, because of the ready activation of (001) glide, giving rise to plastic deformation even below $300{ }^{\circ} \mathrm{C}$ (Bons, 1988). The stable (i.e., aseismic) and low-friction behavior of chlorite (Ikari et al., 2009) may be related to such intracrystalline deformation. Although the chlorite content in the present study is $<12 \mathrm{wt} \%$ within intensely cleaved samples, Collettini et al. (2009) experimentally showed that even a small amount of phyllosilicates (in their case, 5\% talc) may control the mechanical behavior of a fault zone if they form a dense network, thereby maintaining the long-term shear strength at a reasonably low level. In the present case, the occurrence of a well-organized network of micas and chlorite may explain the aseismic behavior of the deep décollement.

\section{Conclusion}


Our mineralogical study on the Kitagawa unit of the Shimanto accretionary prism showed that the growth of paragenetic mica and chlorite during anchizonal-epizonal low-grade metamorphism contributed to the development of a pervasive slaty cleavage. The reactions proceeded without large elemental flux or modal fluctuations in phyllosilicate content. The mechanical transition from seismic to aseismic behavior along the deep décollement is attributable in part to the progressive development of subhorizontal mica and chlorite networks, similar to those observed at the surface.

\section{Acknowledgements}

Fabrizio Storti and two anonymous reviewers are thanked for their constructive comments which helped to improve the manuscript. This work was financially supported by a Grant-in-Aid for Scientific Research from MEXT-KAKENHI 21107005.

\section{References}

Abad, I., G., Gutierrez-Alonso, F., Nieto, I., Getner, A., Becker and A., Cabero (2003) The structure and the phyllosilicates (chemistry, crystallinity and texture) of Talas Ala-Tau (Tien Shan, Kyrgyz Republic): comparison with more recent subduction complexes. Tectonophys. $365,103-127$.

Ague, J.J. (1991) Evidence for major mass transfer and volume strain during regional metamorphism of pelites. Geology, 19, 855-858.

Ahn, J.H., and D.R., Peacor (1985) Transmission electron microscopic study of diagenetic chlorite in Gulf Coast argillaceous sediments. Clays and Clay Minerals, 33, 228-236. 
Aldega, L., and D.D., Eberl (2005) Detrital illite crystals identified from crystallite thickness measurements in siliciclastic sediments. American Mineralogist, 90, 1587-1596.

Beautner, E.C., and E.G., Charles (1985) Large volume loss during cleavage formation, Hamburg sequence, Pennsylvania. Geology, 13, 803-805.

Blanpied, M.L., D.A., Locknar, and J.D., Byerlee (1991) Fault stability inferred from granite sliding experiments at hydrothermal conditions. Geophysical Research Letters, 18, 609-612.

Blanpied, M.L., D.A., Locknar, and J.D., Byerlee (1995) Frictional slip of granite at hydrothermal conditions. Journal of Geophysical Research, 100, 13,045-13,064.

Bons, A.J. (1988) Deformation of chlorite in naturally deformed low-grade rocks. Tectonophysics, 154, 149-165.

Brandon, M.T., J.G., Feeham, and S.R., Paterson (1991) Volume strain associated with pressure-solution deformation in sandstones from high P-low T terrains: A third of the rock is missing! Geol. Soc. Am. Abs. with Programs, 23, A362.

Brown, K.M., A., Kopf, M.B., Underwood, and J.L., Weinberger (2003) Compositional and fluid pressure controls on the state of stress on the Nankai subduction thrust: A weak plate boundary. Earth and Planetary Science Letters, 214, 589-603.

Byrne, T. (1984) Structural evolution of mélange terranes in the Ghost Rocks Formation, Kodiak Island, Alaska, in Mélanges, their origin and significance, edited by L. Raymond, pP 21-51, Special Publication of Geological Society of America, 198.

Caillère, S., S., Henin, and M., Rautureau (1982) Mineralogie des Argiles. Act. Sci. Agr. De L'I.N.R.A. 8, Masson, Paris.

Calvert, A.J., K., Ramachandran, H., Kao, and M.A. Fisher (2006) Local thickening of the 
Cascadia forarc crust and the origin of seismic reflectors in the uppermost mantle. Tectonophysics, 420, 175-188.

Collettini, C., A., Niemeijer, C., Viti, and C., Marone (2009) Fault zone fabric and fault weakness. Nature, 462, 907-U98,

Cowan, D.S. (1982) Deformation of partly dewatered and consolidated Franciscan sediments near Piederas Blancas Point, California, in: L.J.K. (Ed.) Trench-Forearc Geology, Geological Society Special Publication, vol. 10, Geological Society of London, pp439-457.

Dalla Torre, M., W.B., Stern, and M., Frey (1994) Determination of white K-mica polytype ratio-comparison of different XRD methods. Clay Minerals, 29, 717-726.

Drief, A., and F., Nieto (2000) Chemical composition of smectites formed in clastic sediments. Implication for the smectite-illite transformation. Clay. Miner., 35, 665-678.

Eberl, D.D. (2003) User guide to RockJock-A program for determining quantitative mineralogy from X-ray diffraction data, 40p. U.S. Geological Survey Open File Report OF 03-78.

Erslev, E.A. (1998) Limited, localized nonvolatile element flux and volume change in Appalachian slates. Geol. Soc. Am. Bull., 110, 900-915.

Guidotti, C.V., and F.P., Sassi (1986) Classification and correlation of metamorphic facies series by means of muscovite $b_{0}$ data from low-grade metapelites: Neues Jahrbuch fur Mineralogie Abhandlungen, 153, 363-380.

Guidotti, C.V., F.P. Sassi, and J.G., Blencoe (1989) Compositional control on the $a$ and $b$ cell dimensions of $2 M_{1}$ muscovite. Eur. J. Mineral. 1, 71-84.

Hara, H., and K., Kimura (2003) New proposal of standard specimens for illite crystallinity measurement: Its usefulness as paleo-geothermal indicator. Bull. Geol. Survey Japan, 54, 
239-50.

Hara, H., and K., Kimura (2008) Metamorphic and cooling history of the Shimanto accretionary complex, Kyushu, Southwest Japan: Implication for the timing of out-of-sequence thrusting. The Island arc, 17, 546-559.

Hashimoto, Y., T., Nakaya, M., Ito, and G., Kimura (2006) Tectonic lithification of sandstone prior to th eonset of seismogenic zone: evidence of tectonic mélange of the Shimanto Belt, Japan. Geochem., Geophys., Geosyst. 7, Q06013, doi:10.1029/2005GC001062.

Hillier, S., and B., Velde (1992) Chlorite interstratified with a 7 a mineral: An example from offshore Norway and possible implications for the interpretation of the composition of diagenetic chlorites. Clay Minerals, 27, 475-486.

Hiller, S. (1993) Origin, Diagenesis, and mineralogy of chlorite minerals in Devonian lacustrine mudrocks, Orcadian basin, Scotland. Clays and Clay Minerals, 41, 240-259.

Hower, J., E.V., Eslinger, M.E., Hower, and E.A., Perry Jr. (1976) Mechanism of burial metamorphism of argillaceous sediments: 1. Mineralogical and chemical evidence. Geol. Soc. Amer. Bull. 87, 725-737.

Hyndman, R.D., M., Yamano, and D.A., Oleskevich (1997) The seismogenic zone of subduction thrust faults. The Island Arc, 6, 244-260.

Hyndman, R.D. (2007) The seismogenic zone of subduction thrust faults: what we know and don't know. In: T. Dixon and J. Moore, Editors, The Seismogenic Zone of Subduction Thrust Faults, Colombia University Press, New York, pp. 15-41.

Ikari, M.J., D.M. Saffer, and C., Marone (2009) Frictional and hydrologic properties of clay-rich fault gouge. Journal of Geophysical Research, 114, B05409, doi:10.1029/2008JB006089. 
James, R.S., A.C. Turnock, and J.J., Fawcett (1976) Stability and phase relations of iron chlorite below $8.5 \mathrm{~kb} \mathrm{P}_{\mathrm{H} 2 \mathrm{O}}$. Contribution to Mineralogy and Petrology, 56, 1-25.

Kameda, J., K., Ujiie, A., Yamaguchi and G. Kimura (in review) Smectite to chlorite conversion by frictional heating along a subduction-zone thrust. Earth and Planetary Science Letters.

Kawabata, K, H. Tanaka, and G., Kimura (2007) Mass transfer and pressure solution in deformed shale of accretionary complex: Examples from the Shimanto Belt, southwest Japan. Journal of Structural Geology, 29, 697-711.

Kilaas, R. (1998) Optical and near-optical filters in high-resolution electron microscopy. Journal of Microscopy, 190, 45-51.

Kimura, G, Y. Kitamura, Y., Hashimoto, A., Yamaguchi, T., Shibata, K., Ujiie, and S., Okamoto (2007) Transition of accretionary wedge structures around the up-dip limit of the seismogenic subduction zone. Earth and Planetary Science Letters, 255, 471-484.

Kondo, H., G., Kimura, H., Masago, K., Ohmori-Ikehara, Y., Kitamura, E. Ikesawa, A., Sakaguchi, A. Yamaguchi, and S., Okamoto (2005) Deformation and fluid flow of a major out-of-sequence thrust located at seismogenic depth in an accretionary complex: Nobeoka Thrust in the Shimanto Belt, Kyushu, Japan. Tectonics, 24.

Kübler, B. (1968) Evaluation quantitative du métamorphism par la cristallinite de l'illité. Etat des progrèss réalizés ces dernières années. Bull. Centre Rech. Pau, S.N.P.A., 2, 385-397.

Lee, J.H., D.R., Peacor, D.D., Lewis, and R.P., Wintsch (1984) Chlorite-illite/muscovite interlayered and interstratified crystals: A TEM/STEM study. Contribution to Mineralogy and Petrology, 88, 372-385.

Lee, J.H., D.R., Peacor, D.D., Lewis, and R.P., Wintsch (1986) Evidence for syntectonic 
crystallization for the mudstone to slate transition at Leigh Gap, Pennsylvania, USA. Journal of Structural Geology, 8, 767-780.

Li, G., D.R., Peacor, R.J. Merriman, B. Roberts, and B.A. Van der Pluijm (1994) TEM and AEM constraints on the origin and significance of chlorite-mica stacks in slates: an example from Central Wales, U.K. Journal of Structural Geology, 16, 1139-1157.

López-Munguira, A., and F., Nieto (2000) Transmission electron microscopy study of very low-grade metamorphic rocks in Cambrian sandstones and shales, Ossa-Morena zone, southwest Spain. Clays and Clay Minerals, 48, 213-223.

Marks, L.D. (1996) Wiener-filter enhancement of noisy HREM images. Ultramicroscopy, 62, 43-52.

Merriman, R.J., and D.R., Peacor (1999) Very low-grade metapelites; mineralogy, microtextures and measuring reaction progress, Pp. 10-60 in: Low-grade metamorphism (M. Frey \& D. Robinson eds.). Blackwell Science, Oxford, UK.

Merriman, R.J. (2002) Contrasting clay mineral assemblages in British Lower Paleozoic slate belts: the influence of geotectonic setting. Clay Miner. 37, 207-219.

Moore, G.F., A., Taira, A., Klaus, L., Becker, B., Boeckel, B.A., Cragg, A., Dean, C.L., Fergusson, P., Henry, S., Hirano, T., Hisamitsu, S., Hunz, M., Kastner, A.J., Maltman, J.K. Morgan, Y., Murakami, D.M., Saffer, M., Sanchez-Gomez, E.J., Screaton, D.C., Smith, A.J., Spivak, J., Steurer, H.J., Tobin, K., Ujiie, M.B., Underwood, and M., Wilson (2001) New insights into deformation and fluid flow processes in the Nankai Trough accretionary prism: results of Ocean Drilling Program Leg 190. Geochemistry Geophysics Geosystems, 2, $2001 G C 000166$. 
Moore, J.C., and D., Saffer (2001) Updip limit of the seismogenic zone beneath the accretionary prism of southwest Japan: an effect of diagenetic to low-grade metamorphic processes and increasing effective stress. Gology, 29, 183-186.

Mukoyoshi, H., H., Hara, and O.K., Ikehara (2007) Quantitative estimation of temperature conditions for illite crystallinity: Comparison to vitrinite reflectance from the Chichibu and Shimanto accretionary complexes, eastern Kyushu, Southwest Japan. Bulletin of the Geological Survey of Japan, 58, 23-31.

Mukoyoshi, H., T., Hirono, H., Hara, K., Sekine, N., Tsuchiya, A., Sakaguchi, and W., Soh (2009) Style of fluid flow and deformation in and around an ancient out-of-sequence thrust: An example from the Nobeoka Teotonic Line in the Shimanto accretionary complex, Southwest Japan. Island Arc, 18, 333-351.

Nedimovic, M.R., R.D., Hyndman, K., Ramachandran, and G..D., Spence (2003) Reflection signature of seismic and aseismic slip on the northern Cascadia subduction interface. Nature, $424,416-420$.

Ohmori, K., A., Taira, H., Tokuyama, A., Sakaguchi, M., Okamura, and A., Aihara (1997) Paleothermal structure of the Shimanto accretionary prism. Geology, 25, 327-330.

Ogawauchi, Y., A., Iwamatsu and A., Tanabe (1984) Stratigraphy and geologic structures of the Shimanto supergroup in the northeastern part of Nobeoka city, Miyazaki Prefecture, Japan, Bulletin of the Faculty of Science of Kagoshima University, 17, 67-88.

Raimbourg, H., T., Shibata, A., Yamaguchi, H., Yamaguchi and G., Kimura (2009) Horizontal shortening versus vertical loading in accretionary prisms. Geochem., Geophys., Geosyst. 10, Q04007. 
Renard, F., A, Park, P. Ortoleva, and J.P., Gratier (1999) An integrated model for transitional pressure solution in sandstones. Tectonophysics, 312, 97-115.

Reynolds, R.C. (1985) NEWMOD: A computer program for the calculation of one-dimensional diffraction patterns of mixed layered clay minerals: Hanover, New Hampsher, R.C. Reynolds.

Reynolds, R.C. (1988) Mixed-layer chlorite minerals. Pp 601-629 in: Hydrous phyllosilicatres (S.W. Bailey eds.) Reviews in Mineralogy, 19. Mineralogical Society of America, Washington, DC.

Sakaguchi, A. (1999) Thermal structure and paleo-heat flow in the Shimanto accretionary prism, Southwest Japan. Island Arc, 8, 359-372.

Sassi, F.P., and A., Scolari (1974) The $b_{0}$ value of the potassium white micas as a barometric indicator in low-grade metamorphism of pelitic schists. Contribution to Mineralogy and Petrology, 45, 143-152.

Schmidt, D., and K.J.T., Livi (1999) HRTEM and SAED investigations of polytypism, stacking disorder, crystal growth, and vacancies in chlorites from subgreenschist facies outcrops. Am. Mineral., 84, 160-170.

Shaw, D.M. (1954) Trace elements in pelitic rocks. Part 1: Variations during metamorphism: Geol. Soc.Am. Bull., 65, 1151-1166.

Spinelli, G.A. and Saffer, D.M. (2004) Along-strike variations in underthrust sediment dewatering on the Nicoya margin, Costa Rica related to the updip limit of seismicity. Geophys. Res. Lett., 31, L04613.

Sweeney, J.J. and Burnham, A.K. (1990) Evaluation of a simple-model of vitrinite reflectance 
based on chemical-kinetics. AAPG Bull., 74, 1559-1570.

Taira, A., I., Hill, J. Firth, U.Berner, W. Bruckmann, T. Byrne, T., Chabernaud, A., Fisher, J.P., Foucher, T., Gamo, J., Gieskes, R., Hyndman, D., Karig, M. Kastner, Y., Kato, S., Lallemand, R., Lu, A., Maltman, G., Moore, K., Moran, G., Olaffson, W., Owen, K., Pickering, F., Siena, E., Taylor, M., Underwood, C., Wilkinson, M., Y., Yamano, and J., Zhang (1992) Sediment deformation and hydrology of the Nankai Trough accretionary prism: synthesis of shipboard results of ODP Leg 131. Earth Planet. Sci. Lett., 109, 431-450.

Toriumi, M., and J., Teruya (1988) Tectono-Metamorphism of the Shimanto Belt. Modern Geology, 12, 303-324.

Underwood, M.B., M.M., Laughland and S.M. Kang (1993) A comparison among organic and inorganic indicators of diagenesis and low-temperature metamorphism, Tertiary Shimanto Belt, Shikoku, Japan. In Underwood, M.B., ed., Thermal Evolution of the Tertiary Shimanto Belt, Southwest Japan: An Example of Ridge-Trench interaction. Geological Society of America Special Paper 273, Boulder, Colorado.

Van Cappellen, E., and J.C., Doukhan (1994) Quantitative transmission X-ray microanalysis of ionic compounds. Ultramicroscopy, 53, 343-349.

Van de Kamp, P.C. (2008) Smectite-illite-muscovite transformations, quartz dissolution, and silica release in shales. Clays Clay Miner., 56, 66-81.

Van der Pluijm, B.A., Lee, J.H., and D.R., Peacor (1988) Analytical electron microscopy and the problem of potassium diffusion. Clays Clay Miner., 36, 498-504.

Velde, B. (1973) Phase equilibria studies in the system $\mathrm{MgO}-\mathrm{Al}_{2} \mathrm{O}_{3}-\mathrm{SiO}_{2}-\mathrm{H}_{2} \mathrm{O}$ : chlorite and associated minerals. Mineralogical Magazine, 39, 297-312. 
Vidal, O., and T., Parra (2000) Exhumation paths of high-pressure metapelites obtained from local equiribria for chlorite-phengite assemblages. Geological Journal, 35, 139-161.

Wang, K, and Y., Hu (2006) Accretionary prism in subduction earthquake cycles: The theory of dynamic Coulomb wedge. Journal of Geophysical Research, 111, B06410, doi:10.1029/2005JB004094.

Ward, C.R., and F., Gómez-Fernández (2003) Quantitative mineralogical analysis of Spanish slates using the Rietveld method and X-ray powder diffraction data. European Journal of Mineralogy, 15, 1051-1062.

Warr, L.N., and A.H.N., Rice (1994) Interlaboratory standardization and calibration of clay mineral crystallinity and crystallite size data. J. Metamorphic Geol. 12, 141-152.

Watanabe, T., D., Epp, S., Uyeda, M., Langseth, and M., Yasui (1970) Heat flow in the Philippine Sea. Tectonophysics, 10, 205-224, doi: 10.1016/0040-1951(70)90107-1.

Wintsch, R.P., C.M., Kvale, and H.J., Kish (1991) Open-system, constant-volume development of slaty cleavage, and strain induced replacement reactions in the Martinsburg Formation, Leigh Gap, Pennsylvania. Geol. Soc. Am. Bull., 103, 916-927.

Wright, T.O. and L.B., Platt (1982) Pressure dissolution and cleavage in the Martinsburg Shale. American Journal of Science, 282, 122-135.

Xu, H., and D.R., Veblen (1996) Interstratification and other reaction microstructures in the chlorite-berthierine series. Contribution to Mineralogy and Petrology, 124, 291-301.

Yang, X.S. (2000) Pressure solution in sedimentary basins: effect of temperature gradient. Earth Planet. Sci. Lett., 176, 233-243.

Yamano, M., S., Honda, and S., Uyeda (1984) Nankai Tourgh: A hot trench? Marine Geophysical 
Research, 6, 187-203.

Yamano, M., M. Kinoshita, S. Goto, and O., Matsubayashi (2003) Extremely high heat flow anomaly in the middle part of the Nankai Trough. Physics and Chemistry of the Earth, 28, 487-497. 


\section{Figure captions}

Table 1. Crystal-chemical parameters and quantitative rock compositions determined by the program RockJock

Table 2. Chemical compositions of micas normalized to $\mathrm{O}_{10}(\mathrm{OH})_{2}$

Table 3. Chemical compositions of chlorite normalized to $\mathrm{O}_{10}(\mathrm{OH})_{8}$

Fig. 1. Geological map of the Kitagawa unit in the northern Shimanto Belt, Kyushu, Japan. The gray level (from light to dark) assigned to the Kitagawa unit corresponds to the intensity of deformation (disruption of bedding and the development of a metamorphic foliation).

Fig. 2. Microstructural evolution from the incipient development of a horizontal foliation (a, b, and b') to intensely deformed domains (c and c'). Cleavage planes are defined by networks of chlorite and mica aligned parallel to the foliation (c, c'). The pairs of images (b-b' and c-c') show the same site under plane- and cross-polarized light, respectively.

Fig. 3. Typical XRD patterns for oriented preparations of the $<2 \mu \mathrm{m}$ fraction in the EG state. Chl=chlorite.

Fig. 4. Typical XRD patterns for random preparations of the $<2 \mu \mathrm{m}$ fraction. Black arrows indicate the 112 and 025 peaks for the $1 M$ and $2 M_{1}$ polytypes, respectively.

Fig. 5. Evolution of the $1 M$-to- $2 M_{1}$ ratio of micas $\left(1 M /\left(1 M+2 M_{1}\right)\right)(\mathrm{a})$, chlorite/mica (b), and total clay content (micas + chlorite) as a function of metamorphic deformation. The weight percent amount of each constituent was determined by RockJock (Eberl, 2003).

Fig. 6. (a) TEM image of a mica packet in an NM sample containing pervasive defect structures. White arrows indicate the sites of layer terminations. (b) Rotationally filtered high-resolution 
TEM (HRTEM) image of a thick mica packet in an NM sample, showing a periodic two-layer ED pattern (inset). Pairs of layers marked by black arrows are arranged in the $1 M$ stacking manner, within areas of $2 M_{1}$ stacking. (c) Thick, well-defined packets (>100 nm) of mica in an StM sample, showing a periodic two-layer ED pattern (inset).

Fig. 7. (a) Thick packet of chlorite in an StM sample. (b) Lattice fringe image of a packet dominated by $7 \AA$ berthierine (white brackets). The black bracket shows a chlorite packet; arrows indicate isolated chlorite layers intergrown with berthierine packets. (c) Rotationally filtered HRTEM image of a chlorite packet containing $7 \AA$ berthierine layers (white arrows); a magnified image is shown in $(\mathrm{d})$. TOT $=$ tetrahedral-octahedral-tetrahedral 2:1 unit layer. $\mathrm{B}=$ brucite-like interlayer sheet. Tetrahedral inversion (white bracket) causes a layer transition from berthierine (top) to chlorite (bottom).

Fig. 8. Chemical compositions of micas plotted as a function of Si. (a) Interlayer cations, total $(\mathrm{Na}+\mathrm{K})$. (b) $\mathrm{Mg}+\mathrm{Fe}$. (c) $\mathrm{Fe} /(\mathrm{Mg}+\mathrm{Fe})$ ratio. Data are normalized to $\mathrm{O}_{10}(\mathrm{OH})_{2}$.

Fig. 9. Atomic ratios of $\mathrm{Al}-\mathrm{Fe}-\mathrm{Mg}$ in chlorite. Also shown are data obtained by EMPA (Raimbourg et al., 2009). 


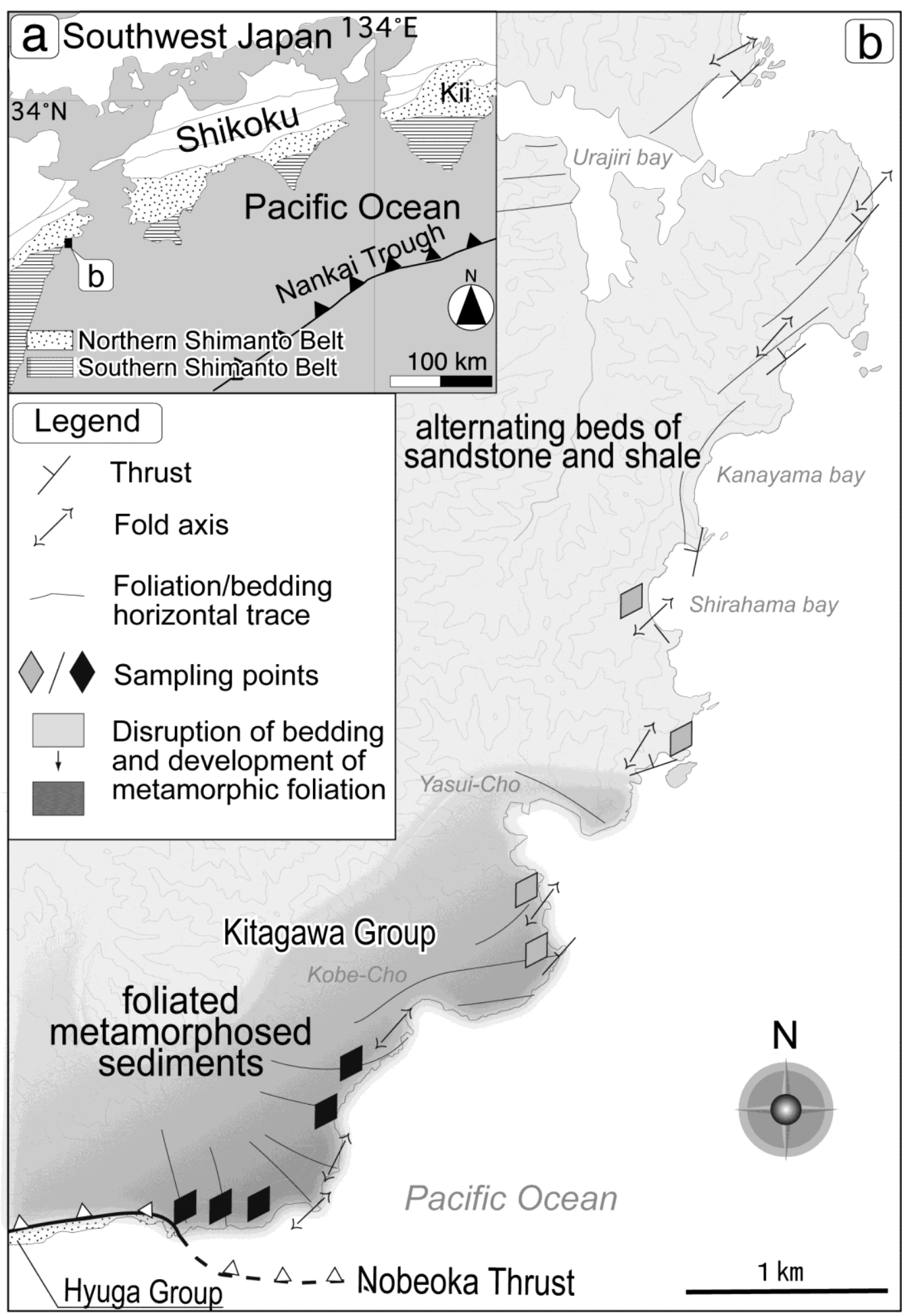

Figure 1 

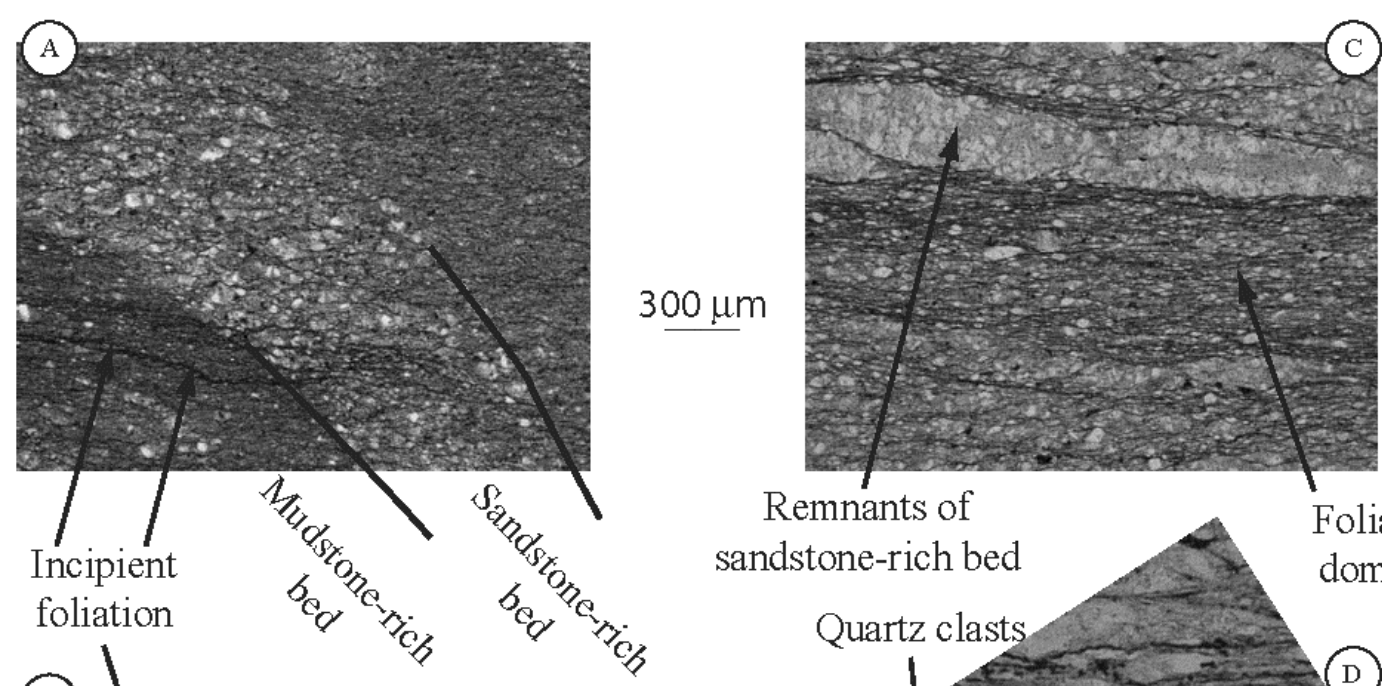

C

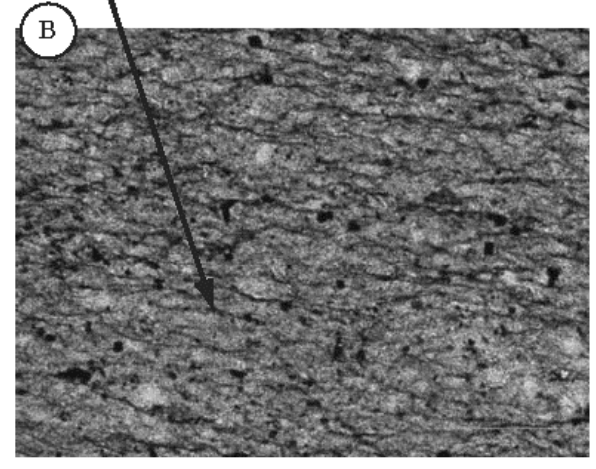

ndstone-rich bed

Foliated

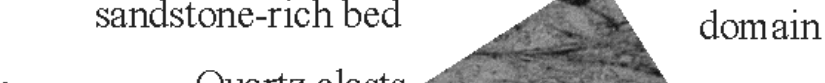

Microcrystalline
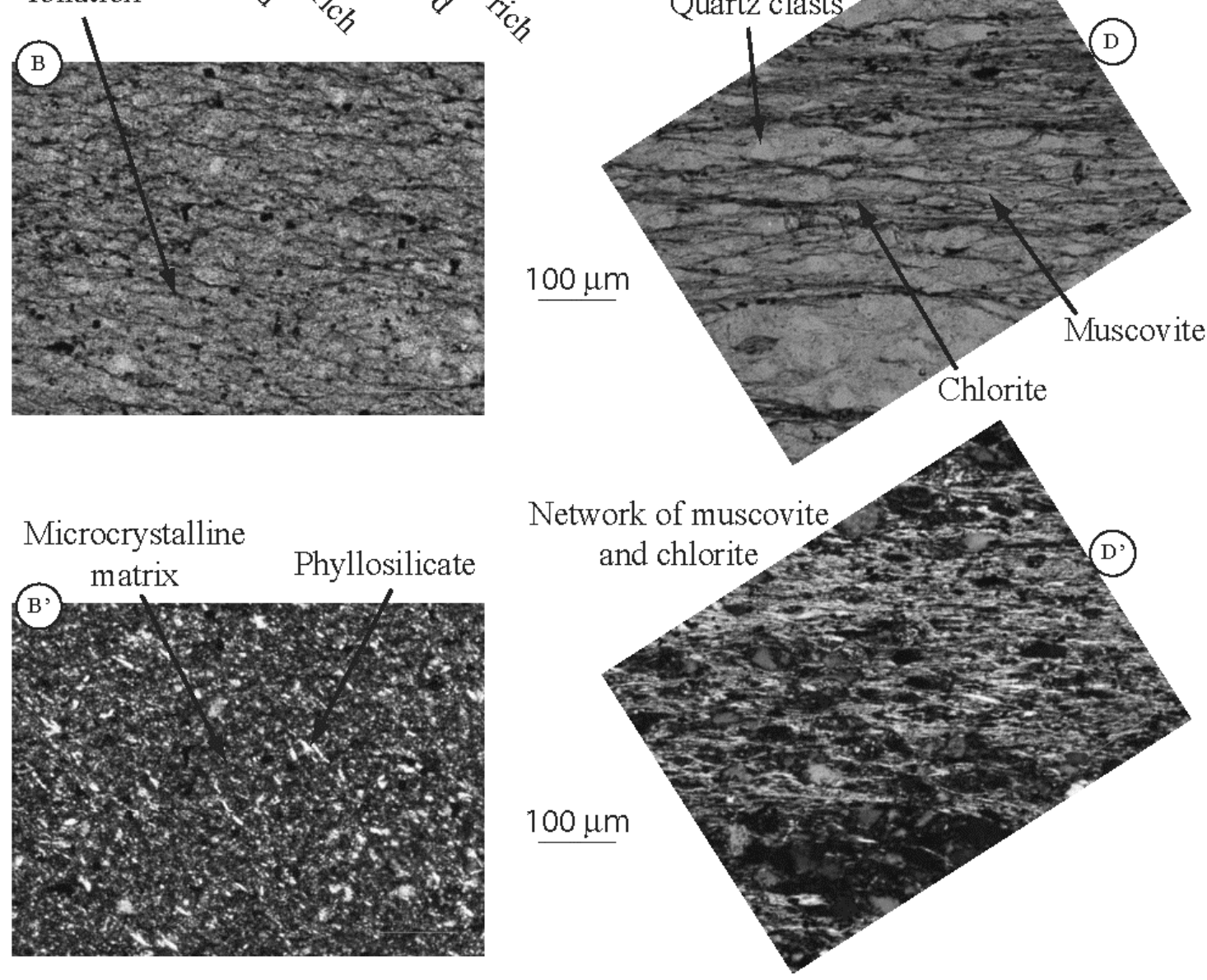

Figure 2 


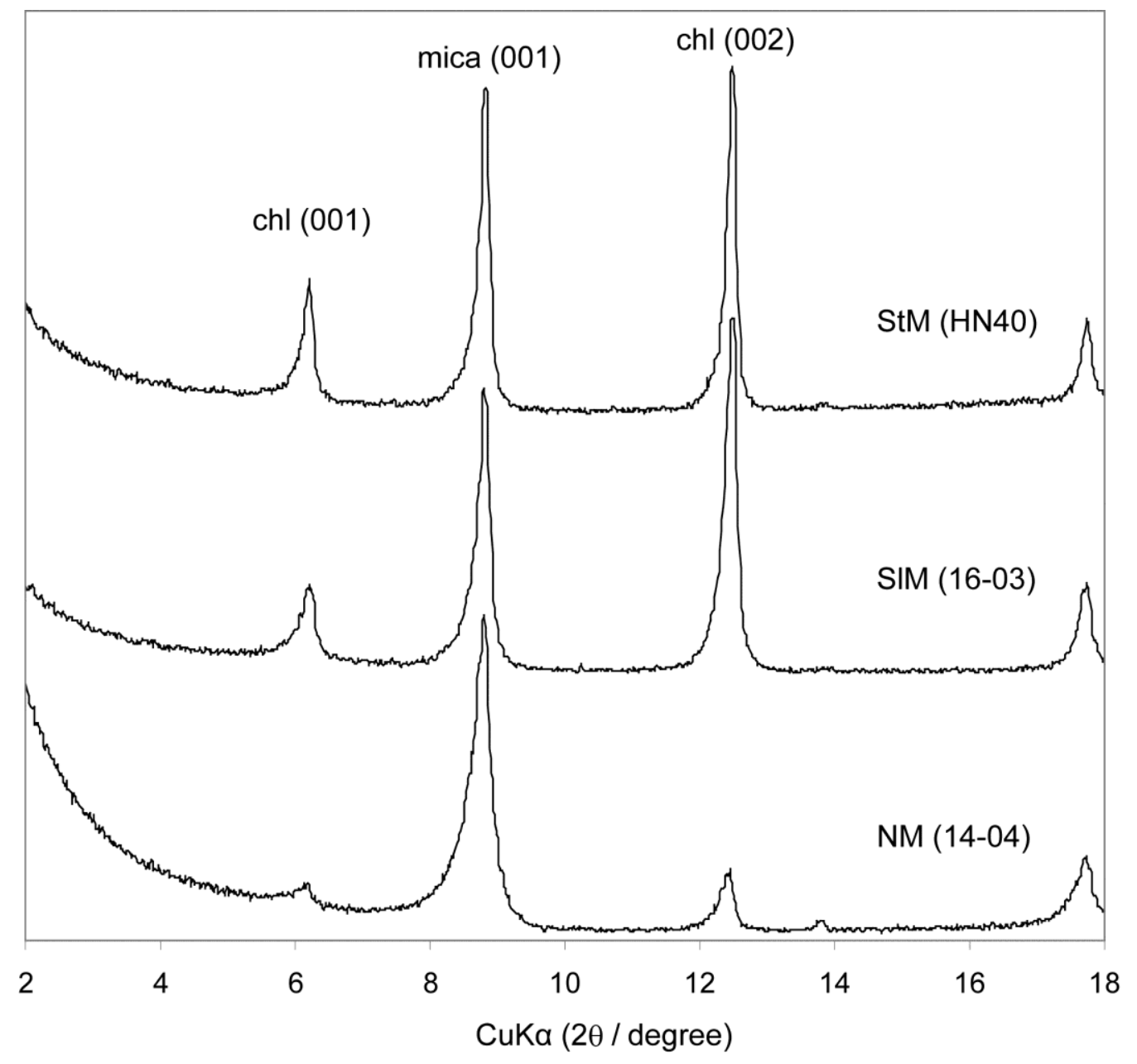

Figure 3 


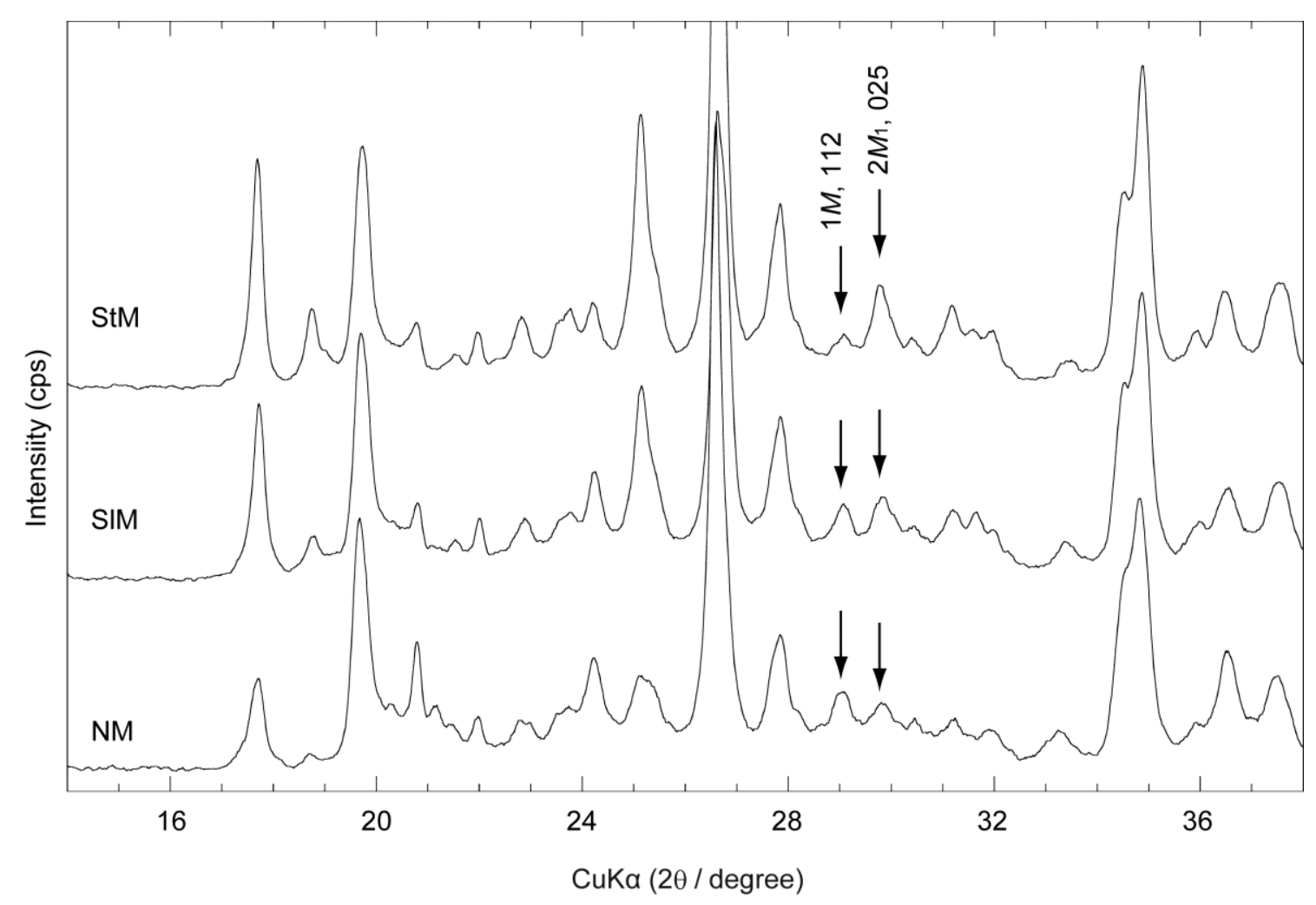

Figure 4 

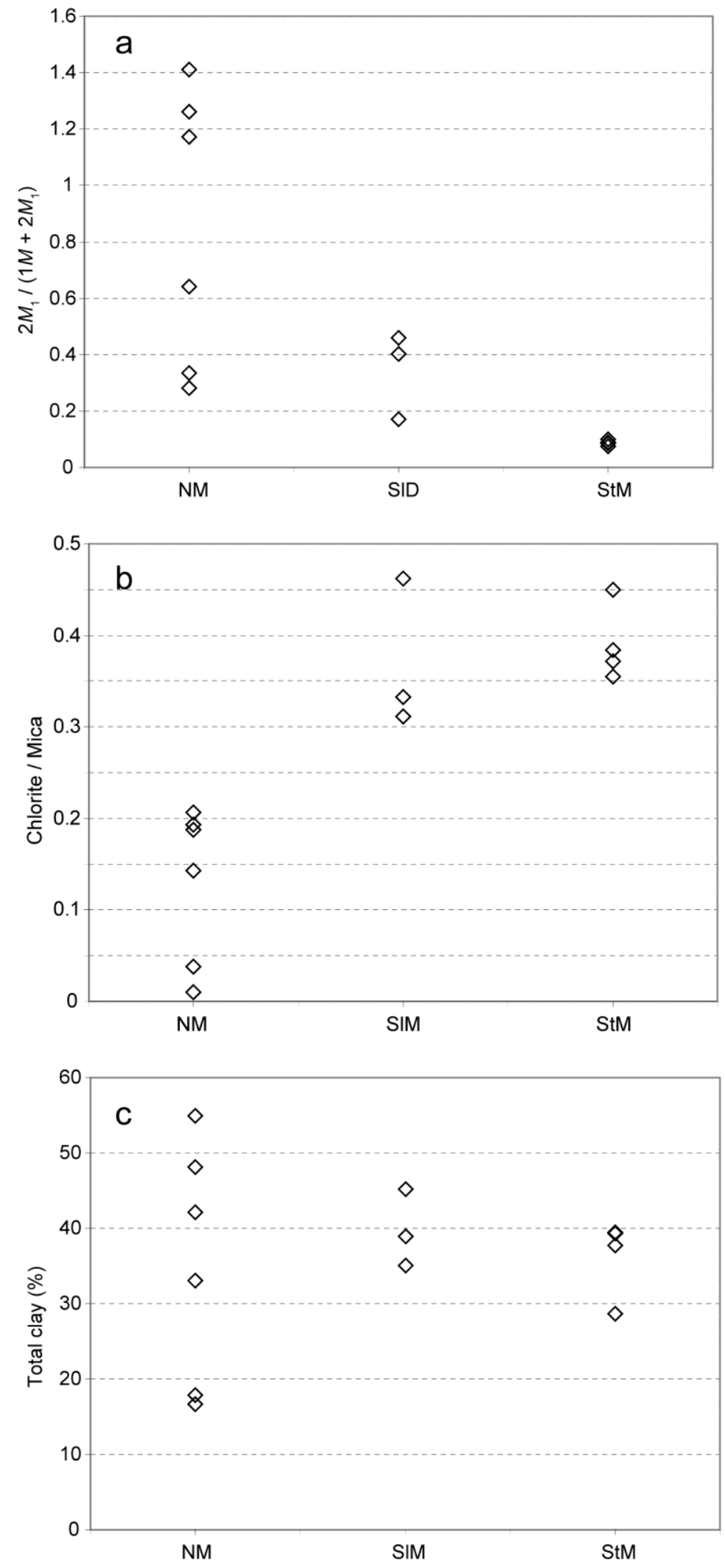

Figure 

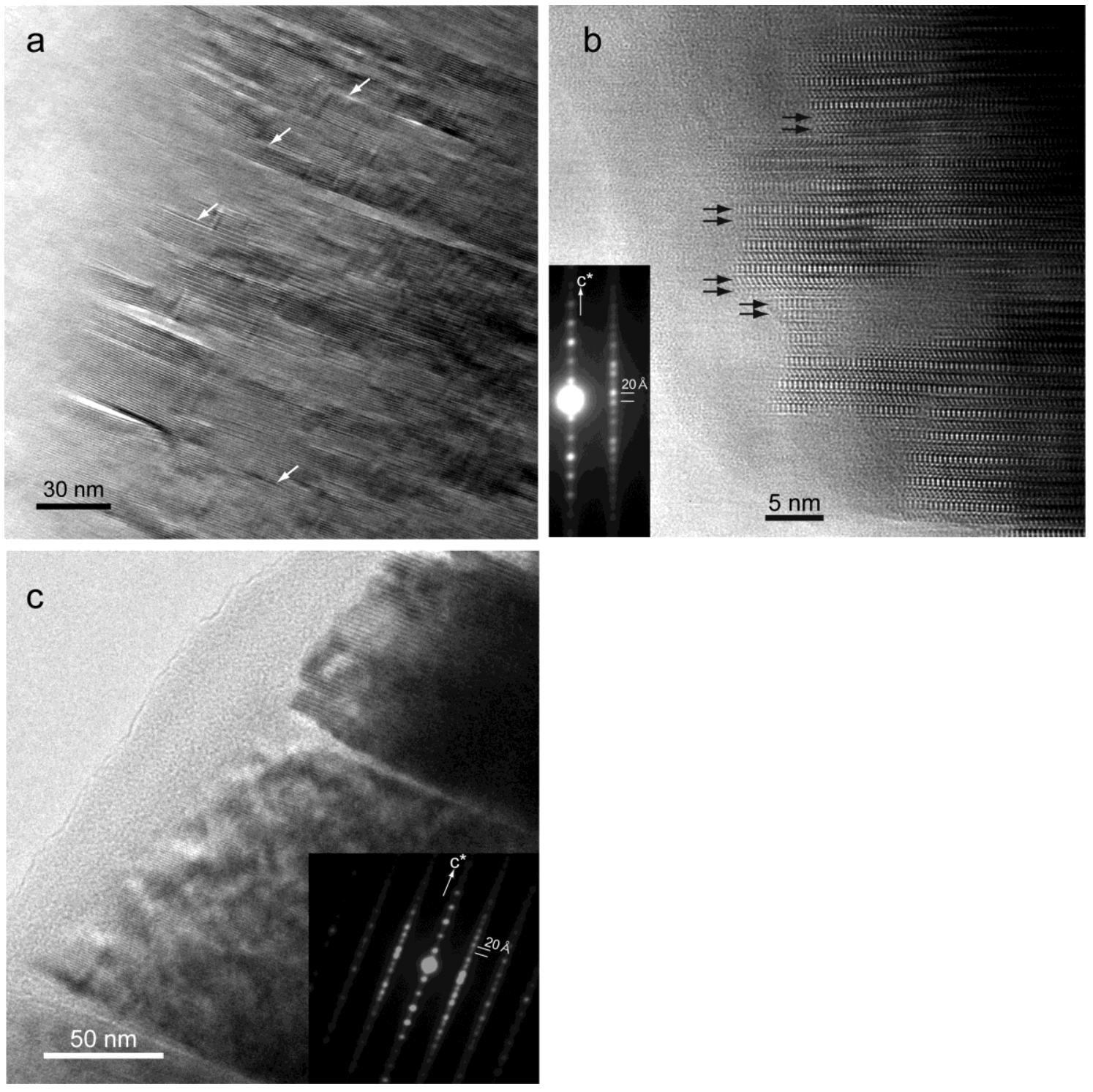

Figure 6 

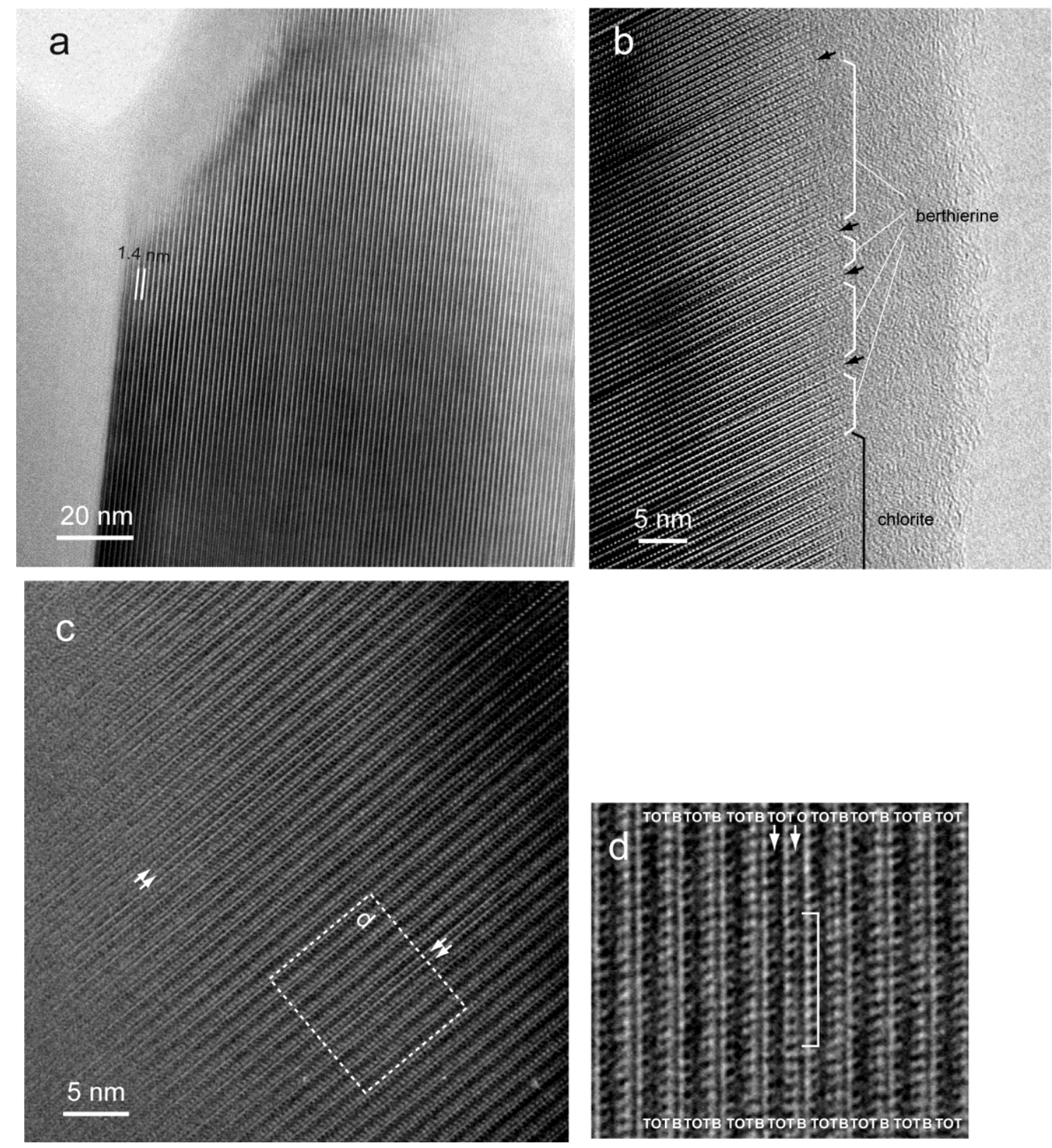

Figure 7 

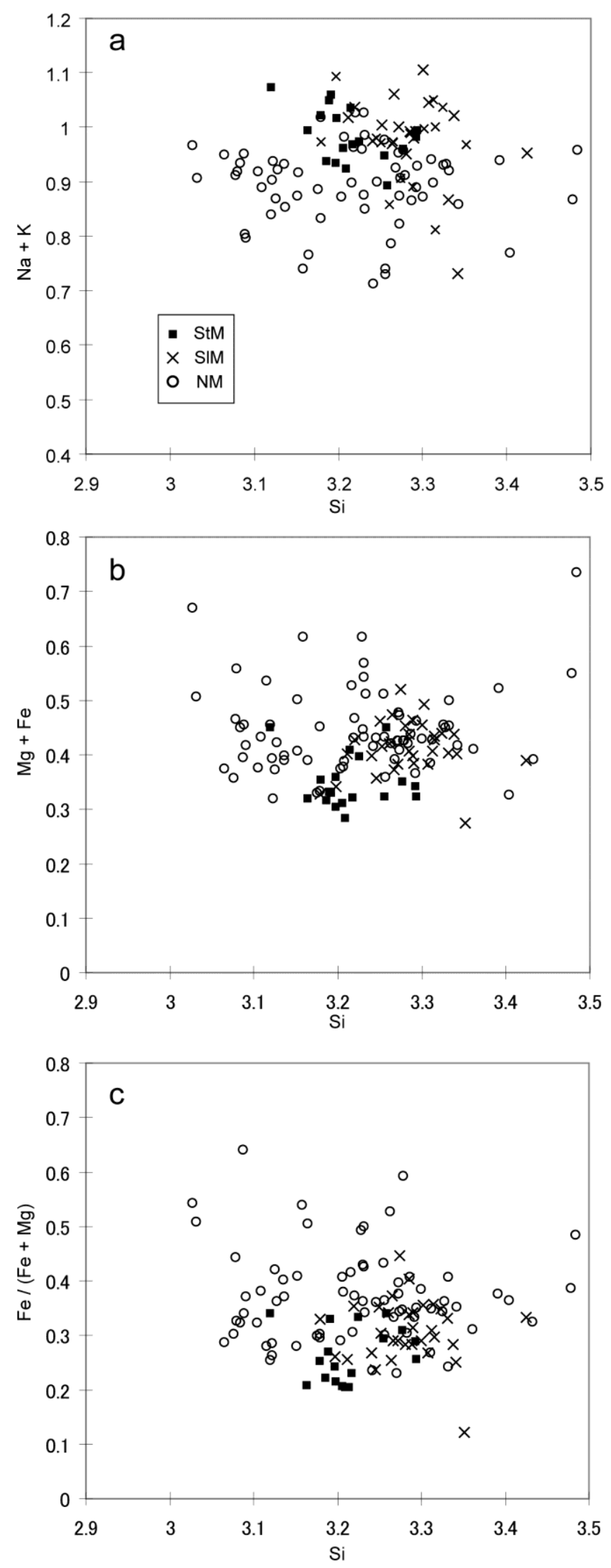
Figure 8

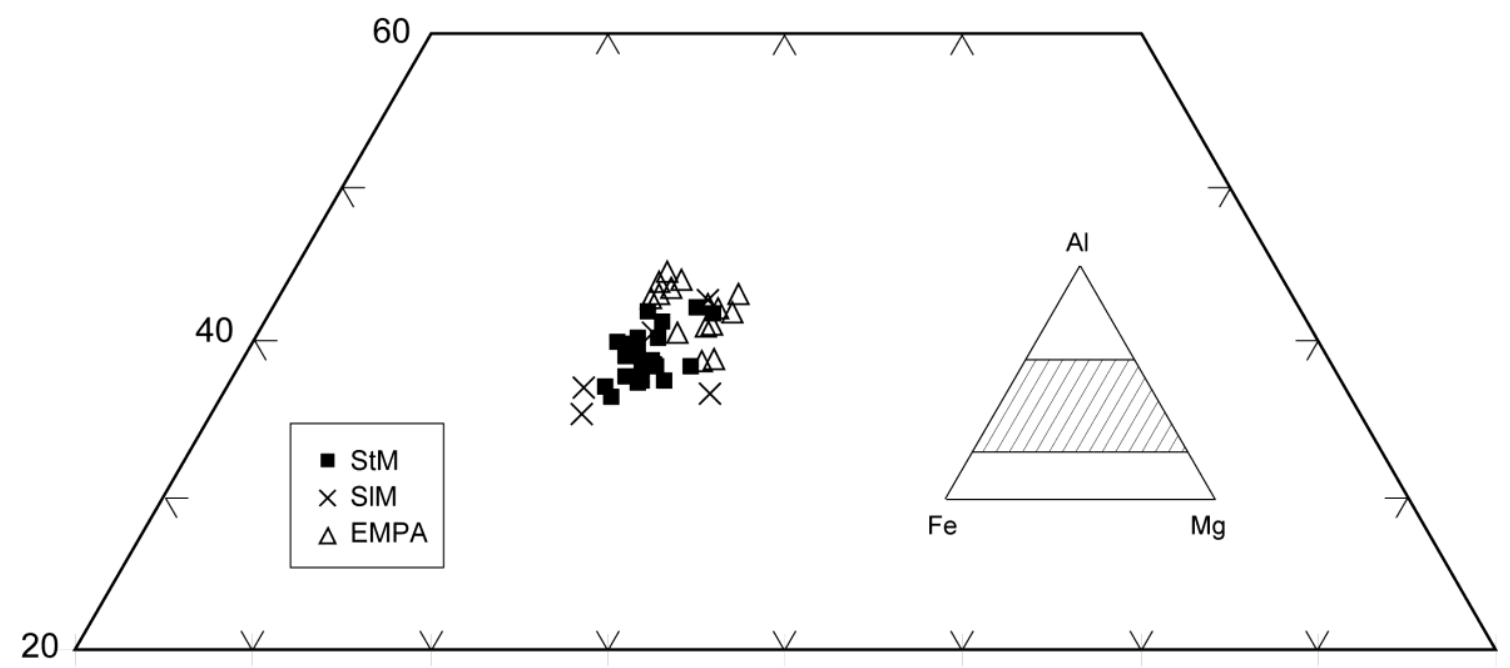

Figure 9

NM

SIM

StM

13_06 14_04 HN18 HN20 HN23 HN24 avg. 16_03 16_05 HN26 avg. 16_07 HN34 HN40 HN41 avg.

$\begin{array}{crrrrrrrrrrrrrrrr}\text { IC }\left(\Delta^{\circ}\right) & 0.208 & 0.410 & 0.191 & 0.243 & 0.245 & 0.345 & 0.274 & 0.238 & 0.228 & 0.294 & 0.253 & \text { n.d. } 0.212 & 0.193 & 0.205 & 0.203 \\ b(\AA) & 9.032 & 9.020 & 9.033 & 9.028 & 9.029 & 9.022 & 9.027 & 9.008 & 9.023 & 9.022 & 9.018 & \text { n.d. } & 9.011 & 9.016 & 9.011 & 9.013 \\ \text { Chl(001)** } & - & 0.371 & 0.256 & 0.248 & 0.251 & 0.359 & 0.282 & 0.262 & 0.235 & 0.297 & 0.265 & \text { n.d. } & 0.187 & 0.180 & 0.209 & 0.192 \\ & & & & & & & & & & & & & & \\ \text { Quartz } & 46.2 & 30.2 & 37.4 & 63.0 & 58.0 & 30.2 & 44.2 & 48.2 & 35.9 & 30.8 & 38.3 & 37.7 & 38.0 & 38.5 & 56.3 & 42.6 \\ \text { Albite } & 19.7 & 22.1 & 20.0 & 19.2 & 24.8 & 14.7 & 20.1 & 15.5 & 25.9 & 22.1 & 21.2 & 23.7 & 22.3 & 22.5 & 15.5 & 21.0 \\ \text { Calcite } & 0.0 & 0.0 & 0.0 & 0.0 & 0.0 & 0.0 & 0.0 & 0.0 & 0.0 & 0.0 & 0.0 & 0.0 & 0.7 & 0.0 & 0.0 & 0.2 \\ \text { Pyrite } & 0.0 & 0.4 & 0.6 & 1.1 & 0.0 & 0.1 & 0.4 & 0.4 & 0.0 & 0.1 & 0.2 & 0.1 & 0.1 & 0.2 & 0.2 & 0.2 \\ \text { Mica 1M } & 8.2 & 27.1 & 7.9 & 5.3 & 7.8 & 24.3 & 13.4 & 2.7 & 7.7 & 9.5 & 6.6 & 2.3 & 2.2 & 1.8 & 1.4 & 1.9 \\ \text { Mica 2M } & 24.5 & 19.2 & 28.1 & 8.2 & 6.7 & 19.2 & 17.7 & 16.1 & 19.1 & 20.7 & 18.6 & 22.6 & 22.0 & 20.0 & 16.6 & 20.3 \\ \text { Chlorite } & 0.4 & 1.8 & 6.0 & 3.2 & 3.4 & 11.5 & 4.4 & 16.2 & 12.1 & 15.1 & 14.5 & 13.4 & 15.1 & 17.8 & 10.7 & 14.2 \\ \text { Total } & 99.0 & 100.8 & 100.0 & 100.0 & 100.6 & 100 * & & 99.1 & 100.6 & 98.1 & & 99.8 & 100.3 & 100.6 & 100.7 & \end{array}$

calculated to be $100 \%$ total. Calculated total by RockJock is $92.1 \%$.

Vidth of chlorite 001 peak at half height $\left({ }^{\circ} 2 \theta\right)$

$=$ not determined

Table 1 


\begin{tabular}{|c|c|c|c|c|c|c|c|c|c|c|c|}
\hline & \multicolumn{5}{|c|}{ NM } & \multicolumn{3}{c|}{ SIM } & \multicolumn{3}{c}{ StM } \\
\hline & $14 \_04$ & HN18 & HN24 & avg. & $16 \_05$ & HN25 & avg. & HN34 & HN40 & avg. \\
\hline $\mathrm{n}$ & 33 & 17 & 20 & 70 & 17 & 16 & 33 & 17 & 7 & 25 \\
\hline $\mathrm{Si}$ & 3.20 & 3.26 & 3.23 & 3.22 & 3.21 & 3.28 & 3.24 & 3.25 & 3.21 & 3.24 \\
\hline${ }^{\mathrm{IV}} \mathrm{Al}$ & 1.66 & 1.60 & 1.64 & 1.64 & 1.49 & 1.63 & 1.56 & 1.66 & 1.72 & 1.68 \\
\hline${ }^{\mathrm{VI}} \mathrm{Al}$ & 0.72 & 0.71 & 0.66 & 0.70 & 0.76 & 0.67 & 0.72 & 0.71 & 0.74 & 0.72 \\
\hline $\mathrm{Fe}$ & 0.14 & 0.20 & 0.19 & 0.17 & 0.13 & 0.14 & 0.13 & 0.11 & 0.07 & 0.10 \\
\hline $\mathrm{Mg}$ & 0.29 & 0.29 & 0.25 & 0.28 & 0.29 & 0.28 & 0.28 & 0.27 & 0.24 & 0.26 \\
\hline $\mathrm{Ti}$ & 0.08 & 0.03 & 0.11 & 0.08 & 0.03 & 0.05 & 0.04 & 0.04 & 0.06 & 0.04 \\
\hline $\mathrm{K}$ & 0.83 & 0.89 & 0.83 & 0.84 & 0.91 & 0.92 & 0.91 & 0.92 & 0.91 & 0.92 \\
\hline $\mathrm{Na}$ & 0.07 & 0.05 & 0.42 & 0.06 & 0.05 & 0.05 & 0.05 & 0.05 & 0.04 & 0.05 \\
\hline$\sum$ inter & 0.90 & 0.94 & 0.87 & 0.90 & 0.96 & 0.97 & 0.96 & 0.98 & 0.95 & 0.97 \\
\hline
\end{tabular}

Table 2.

\begin{tabular}{ccccl} 
& SIM & \multicolumn{3}{c}{ StM } \\
& 16_05 & 16_07 & HN34 & avg. \\
\hline $\mathrm{n}$ & 5 & 17 & 7 & 24 \\
$\mathrm{Si}$ & 2.84 & 2.73 & 2.68 & 2.71 \\
${ }^{\mathrm{IV}} \mathrm{Al}$ & 1.53 & 1.53 & 1.55 & 1.54 \\
${ }^{\mathrm{VI}} \mathrm{Al}$ & 1.12 & 1.20 & 1.26 & 1.22 \\
$\mathrm{Fe}$ & 2.67 & 2.69 & 2.71 & 2.70 \\
$\mathrm{Mg}$ & 1.59 & 1.61 & 1.60 & 1.60 \\
$\mathrm{Ti}$ & 0.03 & 0.07 & 0.06 & 0.07
\end{tabular}

Table 3. 